\title{
Family Structure and the Education Gender Gap: Evidence from Italian Provinces
}

\author{
Graziella Bertocchi* and Monica Bozzano ${ }^{\dagger}$ \\ *University of Modena and Reggio Emilia, CEPR, and IZA, Viale Berengario 51, 41121 \\ Modena, Italy. e-mail: graziella.bertocchi@unimore.it. \\ ${ }^{\dagger}$ University of Modena and Reggio Emilia, Viale Berengario 51, 41121 Modena, Italy. \\ e-mail: monica.bozzano@unimore.it.
}

\begin{abstract}
We investigate the determinants of the education gender gap in Italy in a historical perspective with a focus on the influence of family structure. We capture the latter with two indicators: residential habits (nuclear versus complex families) and inheritance rules (partition versus primogeniture). After controlling for economic, institutional, religious, and cultural factors, we find that over the 1861-1901 period family structure is a driver of the education gender gap, with a higher female-to-male enrollment rate ratio in upper primary schools being associated with nuclear residential habits and equal partition of inheritance. We also find that only the effect of inheritance rules persists over the 1971-2001 period. (JEL codes: E02, H75, I25, J16, N33, O15).
\end{abstract}

Keywords: education gender gap, Italian unification, family types, inheritance, institutions, religion, convergence

\section{Introduction}

Over a century and a half after the unification of the country in 1861 , in Italy the education gender gap has been gradually closing, and even reversing in recent years. This article investigates its determinants by exploring the comparative effect of economic, institutional, religious, and cultural factors in historical perspective. The main focus of our investigation is the potential influence of family structure on gendered human capital accumulation. Despite the fact that Italy - within cross-country investigations - is often treated as homogeneous in this respect, in fact, it does exhibit significant variations in its family structure along several dimensions.

The industrialization process that took place in the 1950s and 1960s has profoundly affected the Italian family structure by provoking a shift of residential habits toward the nuclear model. However, the nuclear model, as opposed to more complex ones, was already diffused even during the 19th century, especially in the South. Likewise, partible inheritance rules have long dominated a large portion of the peninsula. At the same time, however, a patriarchal and authoritarian attitude was also prevalent within Italian families, according to a rigid hierarchy that emphasized gender roles (Barbagli 1987). Despite the fact that family structure, in 
Italy and elsewhere, not only went through a time evolution but also responded to different rules in rural versus urban contexts and also across different social classes, it was possible to identify a relatively stable geographical differentiation of family models by the time the country was unified.

To classify family structure, we monitor two specific dimensions, reflecting residential habits and rules of inheritance, respectively. Therefore, we distinguish between nuclear versus complex residential habits and between equal partition versus primogeniture. Our hypothesis is that both dimensions may have influenced the position of women within the family and in society, leading through the centuries to a shift in cultural values and beliefs that might have persistently changed the status of women, and in particular their ability to acquire human capital.

Nuclear residential habits reflect a more liberal, rather than authoritarian, attitude. In a context where authority is largely a monopoly of males, we conjecture that a more liberal family structure should favor a more advantageous position of women. Partible inheritance is associated with more equality among children including females, if compared with alternative customs such as male primogeniture or discretion, which typically favor male heirs. In turn, augmented property rights should be associated with a broader set of rights, including access to education. We also evaluate the potential additional role of female age at marriage, since age at marriage is another important indicator of the degree of subordination of women with respect to men and therefore of gender inequality. Low age at marriage for women is in fact associated with inequality between the sexes and different tasks and responsibilities. Moreover, we combine these three indicators - residential habits, inheritance rules, and female age at marriage - to obtain an extended version, adapted to Italy, of the classification of family structure due to Todd (1990). While Todd (1990) only considers residential habits and inheritance rules, we also evaluate the combined potential role of female age at marriage, following the attention paid by Hajnal (1965, 1982), and by Barbagli (1987) and Del Panta et al. (1996) with specific focus on Italy, to this additional dimension.

Our analysis of the effect of family structure on the education gender gap is based on a comprehensive newly assembled database reporting primary school enrollment, by gender, across 69 provinces over a 20-year subsample covering the 1861-1901 period, which captures the crucial initial 40 years of the country. At this critical juncture for the history of the country, we still observe a sizeable gender gap even in compulsory primary school. We complete our database with information on relative contemporaneous schooling attainment, with a focus on higher levels such as secondary and tertiary schools, where a gender gap is still likely to linger on in the present days. Besides family structures, among the 
correlates we explore are indicators for economic, institutional, and religious factors. During this period, Italy indeed represents a microcosm which exhibits rich variations along all these dimensions. As a result, we present evidence that family structure is a robust correlate of the education gender gap during the historical period under examination, with a higher female-to-male ratio in enrollment in primary school being associated with nuclear residential habits and with equal partition of inheritance. Moreover, we find that the impact of family structure is persistent but, over a contemporaneous dataset covering the years 1971 and 2001, only the latter dimension still matters. However, despite the fact that our results are consistent across different specifications and after controlling for a large set of potentially confounding factors, we should still be cautious in interpreting our results as causal, since we still lack an underlying theoretical model of the effect of family structure on the education gender gap.

The rest of the article is organized as follows. In Section 2, we summarize the relevant literature. In Section 3, we present our newly collected dataset. Section 4 contains the empirical analysis on the historical education gender gap. In Section 5, we turn to the contemporaneous education gender gap. We conclude in Section 6.

\section{Literature}

The literature on girls' education in historical perspective has looked at multiple angles across time and space. Goldin (1998) and Goldin et al. (2006) study the evolution of secondary and tertiary education, respectively, for American women during the 20th century. ${ }^{1}$ Becker and Wößmann (2008) investigate the determinants of girls' education over 19th-century data for Prussia, with a focus on the positive influence of Protestantism. ${ }^{2}$ The education gender gap in Italy during the 19th century is studied by Bertocchi and Bozzano (2013), who search for their deep, long-term determinants and find a beneficial influence on women's outcomes of the medieval pattern of commerce, along the routes that connected Italian cities among themselves and with the rest of the world. ${ }^{3}$ In a more general setting, the long-term determinants of the gender gap have been studied by Galor and Weil (1996), who model the link between

1 Fernandez and Wong (2011) analyze the recent disappearance of the education gender gap in the USA.

2 Protestantism was nearly absent in Italy throughout the period under examination.

3 For Italy, see also Bertocchi et al. (2014), who document a reversal of the education gender gap in the post-World War II period, and Bozzano (2014), who adapts the Global Gender Gap Index to contemporaneous Italian data. 
women's inferior physical strength and their potential accumulation of human capital, and Alesina et al. (2013), who test the hypothesis that cultivation techniques requiring the plough determined the historical gender division of labor, ${ }^{4}$ while Becker and Barro (1988) analyze the trade-off between the quantity and quality of children, the latter depending on the children's human capital. With respect to this literature, our contribution is to focus on the influence of family culture on the education gender gap. ${ }^{5}$

We shall present below four streams of the literature on gender roles, focusing, respectively, on the role of the family, which is our main focus, as well as the influence of development, institutions, and religion as potential determinants.

\subsection{Gender and family structure}

The potential role for family structure in determining women's position has attracted a growing literature, following seminal work by Banfield (1958), Coleman (1990), and Todd (1990) on the general relevance of family ties for socioeconomic outcomes.

Todd (1990) develops a classification of family types organized along two leading axes. The first axis focuses on the relationship between parents and children, which can be captured by residential habits. On this basis, families can be classified as 'liberal', that is, nuclear families where children leave after marriage, or 'authoritarian', that is, extended (stem, or communitarian) families where different generations live together. The second axis focuses on the relationship between siblings, which in turn can be captured by inheritance rules. The latter can be differentiated into 'equal' and 'unequal' ways to distribute family's wealth, where inequality may involve primogeniture, unigeniture, or the absence of formal rules. ${ }^{6}$

The combination of the above two axes leads to the following four family types: the absolute nuclear family, 'liberal' and 'unequal' (since no formal inheritance rules apply); the egalitarian nuclear family, 'liberal' and 'equal'; the stem family, 'authoritarian' and 'unequal'; and the communitarian family, 'authoritarian' and 'equal'. Todd also acknowledges the presence of a fifth type, the incomplete stem family, particularly widespread at the border between different national entities, which combines the 'authoritarian' model with inheritance customs which are de jure but not de facto egalitarian. To determine the distribution of these family types within Western Europe, Todd applies the 'regressive method' due

4 The plough system applied to the entire territory of Italy.

5 See Spolaore and Wacziarg (2013) for a broad survey of the literature studying the long-term impact of cultural traits on a range of economic outcomes.

6 See Bertocchi (2006) on the historical evolution of inheritance practices. 
to Bloch (1949), which consists in starting with the most recent and complete data and from those to go back to historical and more fragmented data. In fact, it is from the patterns documented for the 1950s and 1960s on the basis of censuses that he can establish strong persistence of the observed family types back to the Middle Age.

The Todd (1990) classification has been applied to the analysis of a number of issues. ${ }^{7}$ More relevant to this article are those related to women's position. Duranton et al. (2009) find that the European regions where egalitarian - rather than absolute - nuclear families tended to predominate have lower female participation in the labor force. Dilli et al. (2013) apply Todd's classification to account for non-European parts of the world and find that it affects gender equality index. Tur-Prats (2014) applies it to an analysis of domestic violence in Spain. An alternative measure of family structure is introduced by Alesina and Giuliano (2010, 2014), who construct a subjective variable measuring the strength of family ties using survey data and show that strong family ties are positively correlated with lower female labor force participation and more traditional attitudes toward women. Galasso and Profeta (2010) compare Todd's classification with the one proposed by Alesina and Giuliano $(2010,2014)$ and find that they are broadly consistent.

While the classification of family types proposed by Todd (1990) is the one which is more commonly applied to economic analysis, in a previous volume, Todd (1984) suggests a different classification that replaces the second axis based on inheritance rules with an alternative one, focused on the relationship between husband and wife and therefore more specifically directed to the analysis of the role of women. ${ }^{8}$ The anthropological categorization of the husband-wife axis is based on the degree of feminism, which is maximum under matrilinearity, minimum under patrilinearity, and intermediate under bilaterality. The anthropological definition of this set of terms is based on kinship. For instance, a family system is considered matrilinear if it confers a prominent role in social life on the

7 Galasso and Profeta $(2010,2013)$ apply Todd's classification to the analysis of European pension systems and redistributive policies. Greif and Tabellini (2012) distinguish between extended and nuclear families to investigate the development patterns of China vs. Europe.

8 The reason why inheritance rules are discarded by Todd (1984) when the focus is on equality between sexes is that he claims that equal partition of inheritance was in fact only applied to sons, thus excluding daughters and implying a lower status for women. However, the exclusion of women from inheritance was not the rule. For instance, Goody (1976) reports that between 1200 and 1800 in European societies property was largely transmitted both to men and women. More specifically in parts of Italy, for example, under the Habsburgs, the legal right to property had been granted to women since the beginning of the Restoration era (Licini 2011). 
kin of the wife. Todd (1984) assigns to the resulting six family types different potentials in terms of development and expansion of mass literacy and also highlights a strong association between literacy and another family characteristic, female age at marriage. The gender gap in literacy, however, is not considered.

Previous research by Hajnal (1965, 1982) had focused on the European Marriage Pattern (EMP), a family model diffused in Northern Europe at least since the 16th century which involves nuclear residential patterns associated with late marriage for both sexes. According to Hajnal, these two features are closely connected: marriage can occur at an early age only in the presence of complex rather than nuclear families, since economic constraints would not allow the formation of an independent family at an early age. The pattern prevailing in Southern Europe, again according to Hajnal, was instead characterized by early marriage and complex families. The EMP has been associated with women's position by De Moor and Van Zanden (2010), who argue that the practice of consensual marriage implied by this model led to distinctive cultural values based on equality between the sexes. This in turn encouraged women to work outside the household, contributing to economic growth. Along similar lines, Foreman-Peck (2011) emphasizes the implications of the higher marriage age for human capital investment for both sexes, but particularly for women, while Voigtlander and Voth (2013) model and test the hypothesis that the Black Death triggered the shift toward the EMP by improving female employment prospects in the pastoral sector.

However, subsequent research has demonstrated that the nexus suggested by Hajnal between nuclear living arrangements and late marriage is not robust. Todd (1990) questions the association between coresidence and late marriage. Indeed, Southern Europe witnessed both early marriage, particularly for women, within nuclear families as well as late marriage within complex ones. Barbagli (1987) and Del Panta et al. (1996) show that examples of the former and the latter combination were diffused in Southern and Central Italy, respectively. ${ }^{9}$

This article contributes to the literature on family structure and women's outcomes by applying Todd's and Hajnal's analysis to the case of Italy and by highlighting the separate roles of residential habits, inheritance rules, and age at marriage in this specific context.

9 Dennison and Ogilvie (2013)'s meta-study confirms that the European Marriage Pattern did not prevail throughout Europe and that its key components did not always coincide; it also casts doubts on the association between this family model and women's empowerment, human capital accumulation, and economic success. 


\subsection{Gender and development}

Turning to the other potential correlates of the gender gap, the literature recently surveyed by Duflo (2012) looks at its nexus with development. With reference to the education dimension, the author argues that, even though the gender gap in primary and secondary enrollment has rapidly gone down during the past decades, it still remains wider in poor countries. This evidence suggests that economic growth can have an important positive impact on gender equality but at the same time that it is generally not sufficient to overcome discrimination. The analysis in this article confirms that economic factors indeed have a limited impact on gender equality in education, which justifies our focus on alternative explanations.

\subsection{Gender, institutions, and educational policies}

Gender outcomes can also be influenced by a wide array of institutions, starting from the institutions that can shape the school system. In the Italian context, the influence of the preunification political regimes on educational policies, including their gendered dimension, has been recognized by the history literature. Female education was largely neglected (Serristori 1842) in most areas, with the exception of Lombardy, Rome, and the Duchy of Parma and Piacenza (Vigo 1971). In many cases, not only the quantity but also the quality of education for girls was inferior, being concerned primarily with knitting and sewing (Incatasciato 1978). In the Bourbons' territories, the law explicitly allowed the hiring of illiterate female teachers (De Mauro 1963). Unification brought the introduction of compulsory primary education for boys and girls and, despite the resilience up to the present day of a North-South divide, activated a regional convergence process in educational attainment, as well as the gradual reduction of the gender gap which is the focus of the present article. We refer to Bertocchi and Spagat (1997), Zamagni (2002), A'Hearn et al. (2011), and Bertola and Sestito (2013) for an exhaustive description of the evolution of the educational system in Italy.

\subsection{Gender and religion}

Finally, the influence of religion on gender roles has been explored by Algan and Cahuc (2006) who, using survey data, show that Catholics, Orthodoxs, and Muslims are more prone to embrace the traditional male breadwinner conception than Protestants and atheists. Within the sociology literature, Esping-Andersen (1990) also associates a conservative view of women and the family with Catholic countries, while Bertocchi (2011) shows that Catholicism is negatively associated with the introduction of women suffrage in the 1870-1930 period. In this article, we aim at 
disentangling a potential role of religion even within a homogeneously Catholic country.

\section{Data and Descriptive Statistics}

To study the long-term determinants of the education gender gap, we compile a database on education outcomes in late 19th-century Italy drawing from various sources. The main source is represented by data collected by the Italian Ministry of Agriculture, Industry and Commerce (MAIC). Our data cover 69 Italian provinces (at 1871 boundaries) in three points in time (1861, 1881, and 1901), spanning the initial 40 years of the unified Kingdom of Italy. It should be stressed that enrollment data at the provincial level are only available until 1901. Data collection at this level of disaggregation is resumed only after World War II. For the same geographical entities, we complete the dataset with contemporaneous (1971 and 2001) census data on education outcomes by gender, taken from Istituto Nazionale di Statistica (ISTAT 2009). We also collect data on the potential determinants of the historical and contemporaneous education gender gap. The variables are described below. We refer to the methodological notes in the Appendix for further details. Below, we also illustrate descriptive statistics and stylized facts that can suggest preliminary hypotheses and considerations.

\subsection{Education}

At unification in 1861, the Kingdom of Italy immediately implemented national educational policies primarily aimed at removing regional disparities across regions. In 1859, even before Rome became the capital, the Casati law disciplined the school system by imposing free and compulsory primary education for boys and girls, starting at age 6 years. The law introduced an initial compulsory 2-year lower primary school (extended to 3 years in 1877 by the Coppino law) followed by a subsequent noncompulsory 2-year upper primary level. The presence of free schools for boys and girls was made mandatory for the local authorities, in the effort to erase the regional differences inherited from the pre-unitary polities and the differential supply and quality of primary schools. However, these legal provisions were enforced only slowly and unevenly, so that spatial disparities are still present throughout the historical period under examination even though ultimately, by the end of the 19th century, these policies proved effective and contributed to a substantial decline, together with a regional convergence, of the gender gap in education. ${ }^{10}$

10 For further details see the references in Subsection 2.3. 
For our dependent variables, we collect historical enrollment rates by gender for total population of primary school age, which consists of the population between 6 and 12 (excluded) years of age. On this basis, we calculate a measure of gender equality given by the female-to-male ratio in enrollment rates in primary school ${ }^{11}$ for the years 1861, 1881, and 1901 . We also compute a separate measure at the lower and upper primary school level, only the former being compulsory. ${ }^{12}$ Beside data by gender, we also include general indicators of schooling defined as the number of pupils enrolled in primary school over the number of children of the corresponding 6-12 school age. Again we disaggregate this measure into a lower and an upper primary school level.

The descriptive statistics reported in Table A2 reveal that in the 18611901 period, the average enrollment rate in primary schools is $52.7 \%{ }^{13}$ and the average female-to-male enrollment ratio is 0.83 (where 1 represents perfect equality). However, there exists significant variation across provinces for both outcomes, ranging from 9.7 to $117.3 \%$ for the enrollment rate $^{14}$ and from 0.05 to 1.51 for the female-to-male enrollment ratio. ${ }^{15}$ Moreover, the picture changes considerably if one distinguishes between the lower and upper primary level: the former displays a female-to-male enrollment ratio of 0.85 ; for the latter, the corresponding figure is 0.55 .

Further inspection of our data reveals that, both at the lower and upper level, enrollment rates increase gradually over the years in the sample. For each year in the sample, gender disparity as captured by the female-tomale enrollment ratio is more pronounced at the upper level. Over time, we observe a gradual closing of the gender gap. Nevertheless, at the end of the period under analysis differences between boys and girls are far from eradicated and remain especially deep at the upper level. In the following discussion, we focus on the female-to-male enrollment ratio at the upper primary level, where gender differences are more pronounced and more persistent.

The maps in Figure 1 show the female-to-male ratio of the enrollment rates at the upper primary level, organized by qurtiles, by province and over time. The darker is the shade of the provincial surface, the larger

11 This measure is equivalent to the UN definition of the Gender Parity Index, where 0 corresponds to extreme inequality and 1 to full equality.

12 Because of lack of data at the provincial level, the denominators of the enrollment rates at the upper and lower levels are always the corresponding 6-12 population figures.

13 Even though schooling was formally mandatory at the lower level, de facto the implementation of the law was gradual and patchy.

14 The reason why enrollment rates can be greater than $100 \%$ is the presence of under-aged and/or overaged enrollment. See the methodological notes in the Appendix for details.

15 For some observations the ratio is larger than 1, which indicates a gender gap in favor of females. 


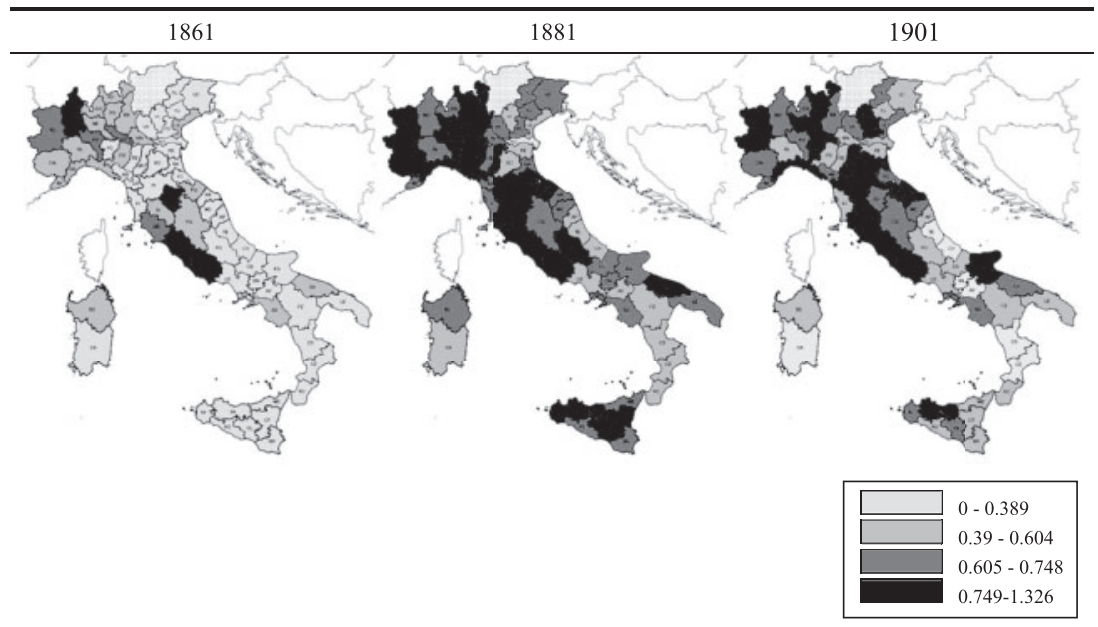

Figure 1 Female-to-male ratio upper primary enrollment rate, 1861-1901. The darker the shade, the higher is the female-to-male ratio upper enrollment rate in the province. Provinces are identified by abbreviations of current provincial names. See the Appendix for sources.

the female-to-male ratio and therefore the higher gender equality. The maps confirm both the time trend and the differentiation across provinces.

Turning to the period following World War II, our measures of education gender equality focuses on the secondary and tertiary levels, since over this sample equality is a well-established fact at the primary level. Rather than to enrollment, these data refer to the number of females and males holding high school and college degrees, respectively. ${ }^{16}$ We take census data for the earliest and latest years currently available, that is, 1971 and 2001. From this perspective, we can evaluate the influence of a wave of educational reforms implemented in the 1960s as well as of the increase of mandatory education to 12 years introduced in $2000 .{ }^{17}$ Taking an initial glance at contemporary data, we find that as of 1971, the position of females both at the secondary and the tertiary level is far from equal from that of males, especially at the tertiary level. The picture changes sensibly by 2001, with a near-closing of the gap at both levels, and in fact almost perfect equality at the tertiary level.

\footnotetext{
16 Flow data about enrollment are not available at the provincial level.

17 For a description of the evolution of the education system in Italy see the references listed in Subsection 2.3.
} 
In the following discussion, we relate our measure of gender equality in education to the potential determinants previously described. More details on the definitions and sources of all variables, as well as on methodological issues, can be found in the Appendix.

\subsection{Family structure}

Our primary indicators for family structure reflect, separately, each of the two axes defined by Todd (1990), that is, residential habits and rules of inheritance. Accordingly, we first define a dummy variable that takes value 1 if the nuclear family pattern was prevailing in the province and 0 otherwise. Similarly, we define a dummy variable that takes value 1 if partible inheritance was prevailing and 0 otherwise. We follow Duranton et al. (2009) for the matching between the information in Todd and geographic units.

As mentioned in subsection 2.1, Todd (1984) defines a third axis concerning the degree of feminism. However, under this classification, Italy belongs entirely to the bilateral type, so that we cannot exploit any variation across provinces.

To account for female age at marriage, building on Hajnal (1982) and Todd (1984), we also collect data from Barbagli (1987) on the percentage of women married below the age of 15 years in 1872-1875. The original source is Direzione di Statistica (DIRSTAT 1877). However, information is available only at the regional level. In this respect, we extend what was already documented by Todd (1984) who, within an international comparison, for year 1840 placed all of Italy with the low-age (namely, below 27 years of age) area. As explained by Barbagli (1987), low age at marriage for women is an important indicator of subordination and inferiority of women within the family, since it is associated with inequality between the sexes and different tasks and responsibilities. ${ }^{18}$

Alternatively, we also account from the Todd (1990) four-way classification (again matched to provincial units following Duranton et al. 2009). However, only three of the Todd family types are relevant for Italy, since the absolute nuclear family is never represented. Moreover, the stem family only appears in its incomplete form, in the area bordering the Austrian Empire. Furthermore, following Hajnal (1982), Todd (1984), Barbagli (1987), and Del Panta et al. (1996), we augment the Todd

18 At least up to unification, no association can be found between late marriage and education acquisition. In fact, in areas where late marriage applies, we find a very high proportion of the population (up to one-third for females in Northern Italy) spending at least some years as domestic servants (Barbagli 1987). This pattern was motivated by the necessity to accumulate sufficient means to start a family and was common to other European countries (Hajnal 1967, 1972). 
(1990) classification to distinguish for Italy between two different models of egalitarian nuclear family, which are, respectively, associated with late and early marriage age for women. As a result, we obtain for Italy four family types, generating a set of four dummies: egalitarian nuclear with late marriage, incomplete stem, communitarian, and egalitarian nuclear with early marriage.

Table A2 reveals that the nuclear family model prevails in about $53 \%$ of the provinces, while partible inheritance does so in about $87 \%$. On average, women marry before age 15 years in only $3 \%$ of the regions, even though the figure is as high as $13 \%$ in the case of Sicily.

Figure 2 illustrates the geographical distribution of the provinces where nuclear families and equal partition prevail, as well the geographic distribution of the four family types based on our adaptation of the Todd (1990) classification. While for equal partition we observe a strong geographical pattern, with primogeniture being concentrated in an area which is close, even though not coincident, with the current North East, the picture is more varied for the coresidence dimension and for the combined family types. Overall, in an international comparison, Italy exhibits rich variation along these dimensions. Indeed, Spain, for instance, exhibits only two family types: the stem family, totally concentrated in the North, and the egalitarian nuclear family in the South. Likewise, England only presents the egalitarian nuclear family in the East and the incomplete stem in the West. To be noticed also is the fact that both in Spain and England the two axes perfectly overlap, so that it is not possible to disentangle the potential effect of coresidence from that of inheritance rules.

\subsection{Economic development}

Our historical correlates for economic development involve measures of the level of wealth and the degree of structural transformation, both with a panel dimension over the 1861-1901 period. We proxy the former with the average height of conscripts aged 20 years. Data on average height for the three waves are taken from A'Hearn et al. (2009). Height is the main indicator employed in the economic history literature because it provides researchers with a measure of the stock of nutritional investment and therefore important indirect information on changes in the well-being of populations (Fogel et al. 1982; A'Hearn et al. 2011). Since the available data neglect female stature, whose trend does not necessarily mimic that of males, as an alternative proxy of wealth we also consider population density data (from the census) and estimates of per capita value added due to Istituto Guglielmo Tagliacarne (2011). To proxy for structural transformation, we employ an index of industrialization computed by Ciccarelli and 


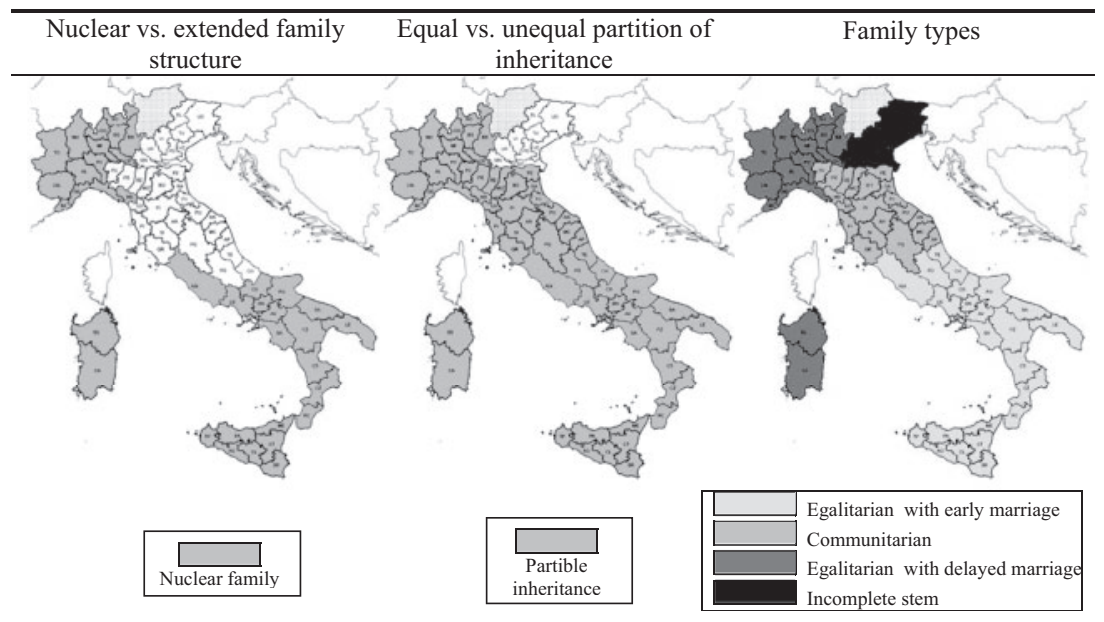

Figure 2 Family structure.

Provinces are identified by abbreviations of current provincial names. See the Appendix for sources.

Fenoaltea (2013) and defined as the share of value added in manufacturing (excluding construction) over the share of the male population over age 15 years (data are from census).

Table A2 shows that the national average height, our proxy for prosperity, is about $163 \mathrm{~cm}$. In Figure 3, we present the geographic distribution by quartiles of height in the 1861-1901 period. Again, the darker is the shade of the provincial surface, the higher is average provincial height. Over the 40 years, height tends to increase but at different speeds, leaving large territorial differences at the end of the period.

We measure contemporaneous development using per capita GDP (Istituto Guglielmo Tagliacarne 2011) in 1971 and 2001.

\subsection{Political regimes}

The period immediately preceding unification, often referred to as Risorgimento, runs from the end of the Napoleonic era in 1815 until 1871 (when Rome becomes the capital). Before this historical turning point, Italy was divided among four main dynasties: the Savoys, ruling roughly in the North West, that is, in Piedmont, Liguria, and Sardinia; the Habsburgs, holding direct control over the Lombardy-Venetia, mostly located in today's North East, as part of the Austrian Empire, as well as indirect control over the Granduchy of Tuscany and other minor Duchies nearby; the Pope, reigning over Rome and the Center South; and the Bourbons, in charge of the South and the Duchy of Lucca. To control 


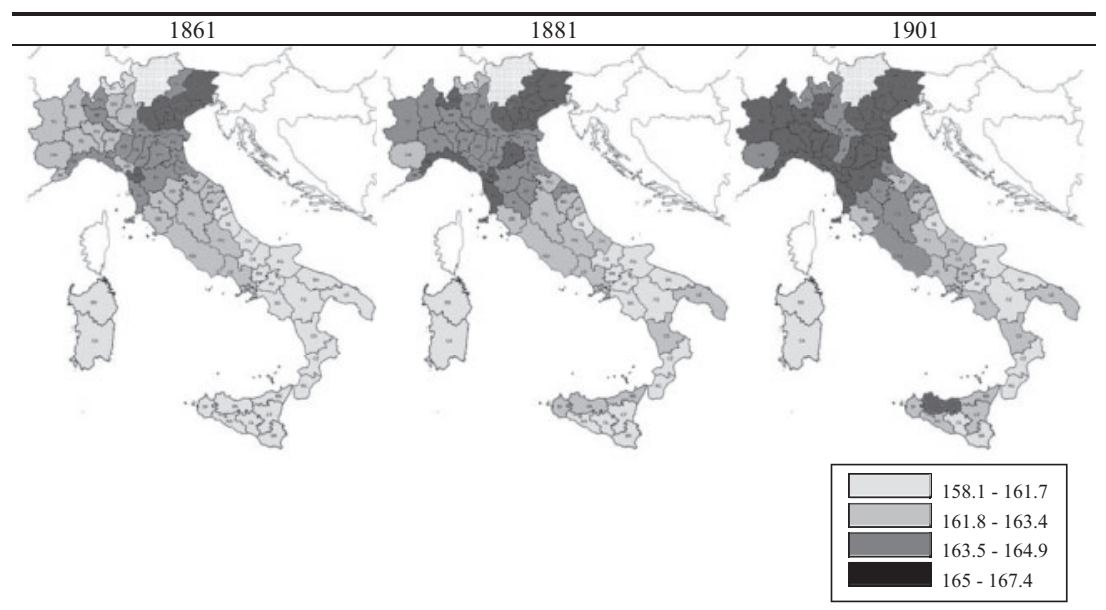

Figure 3 Average height of conscripts, 1861-1901.

The darker the shade the higher is average height of conscripts in each year. Provinces are identified by abbreviations of current provincial names. See the Appendix for sources.

for the legacy of deeply rooted political institutions that may have shaped educational policies and the evolution and persistence of gender disparities, we construct a set of four dummies for the prevailing political regimes the 1815-1861 period, that is, Savoys, Habsburgs, Pope, and Bourbons.

Figure 4 illustrates the political geography of Italy according to our classification. In the provinces previously belonging to the Kingdom of Sardinia and in Lombardy-Venetia, we observe larger female-to-male ratios. At the opposite, we find the Bourbons' territories, largely located in the South. These discrepancies can be explained, at least in part, by educational policies. For instance, schooling was compulsory until age 12 years in Lombardy-Venetia. As previously mentioned, the political unification of the country implied the adoption and implementation of national educational policies.

For the analysis of contemporaneous data we refer to four current macro-regions (North West, North East, Center, and South), which partially overlap with the historical political regimes but better capture the postwar spatial distribution of policies and institutions.

\subsection{Religion}

While Italy has been historically a homogeneously Catholic country, we still aim at exploring the potential role of religion through various measures of the presence of the Church. Our first measure is the distance from 


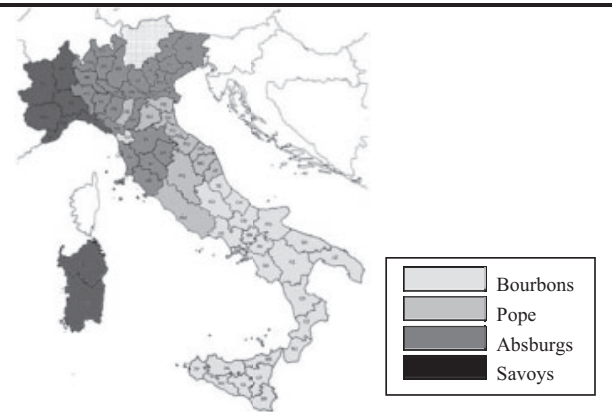

Figure 4 Preunification political regimes.

Provinces are identified by abbreviations of current provincial names. See the Appendix for sources.

Rome of the main city or town of each province. ${ }^{19}$ Second, we collect information from Bianchi (1845) and Palmieri (1857) about the number of parish churches in each province before Italy's unification and construct their density by dividing it by the provincial surface. Since the creation of parish churches is historically determined and does not necessarily reflect the intensity of the influence of religion around unification, we also rely on two additional indicators. Our third indicator is the fraction of Catholic (as opposed to secular) teachers over the total number of teachers in 1862 (from MAIC 1865 and 1874). To be noticed is that other cults were nearly absent in Italy throughout the period under examination. Our fourth indicator measures the presence of the clergy using the number of priests (taken from Amati 1860, and Correnti 1858) over population in 1857 , even though we have this information only at the regional level.

Table A2 shows that the density of parish churches is on average 13 per squared kilometer, over a range of 1-70. It is highest in Sicily and some other southern provinces. The proportion of Catholic teachers is on average almost $36 \%$ of total teachers, ranging from 2 to $85.3 \%$, and is larger in the North and in Sardinia. In Figure 5 we illustrate two of the variables reflecting the influence of religion.

\subsection{Geography}

To capture residual factors such as the presence of different factor endowment, we also collect data on latitude, longitude, and the provincial fraction of plain terrain. Summary statistics are reported in Table A2.

19 Becker and Wößmann (2009) employ distance from Wittenberg, Luther's city, to measure the influence of Protestantism in late nineteenth century Prussia. 
G. Bertocchi and M. Bozzano

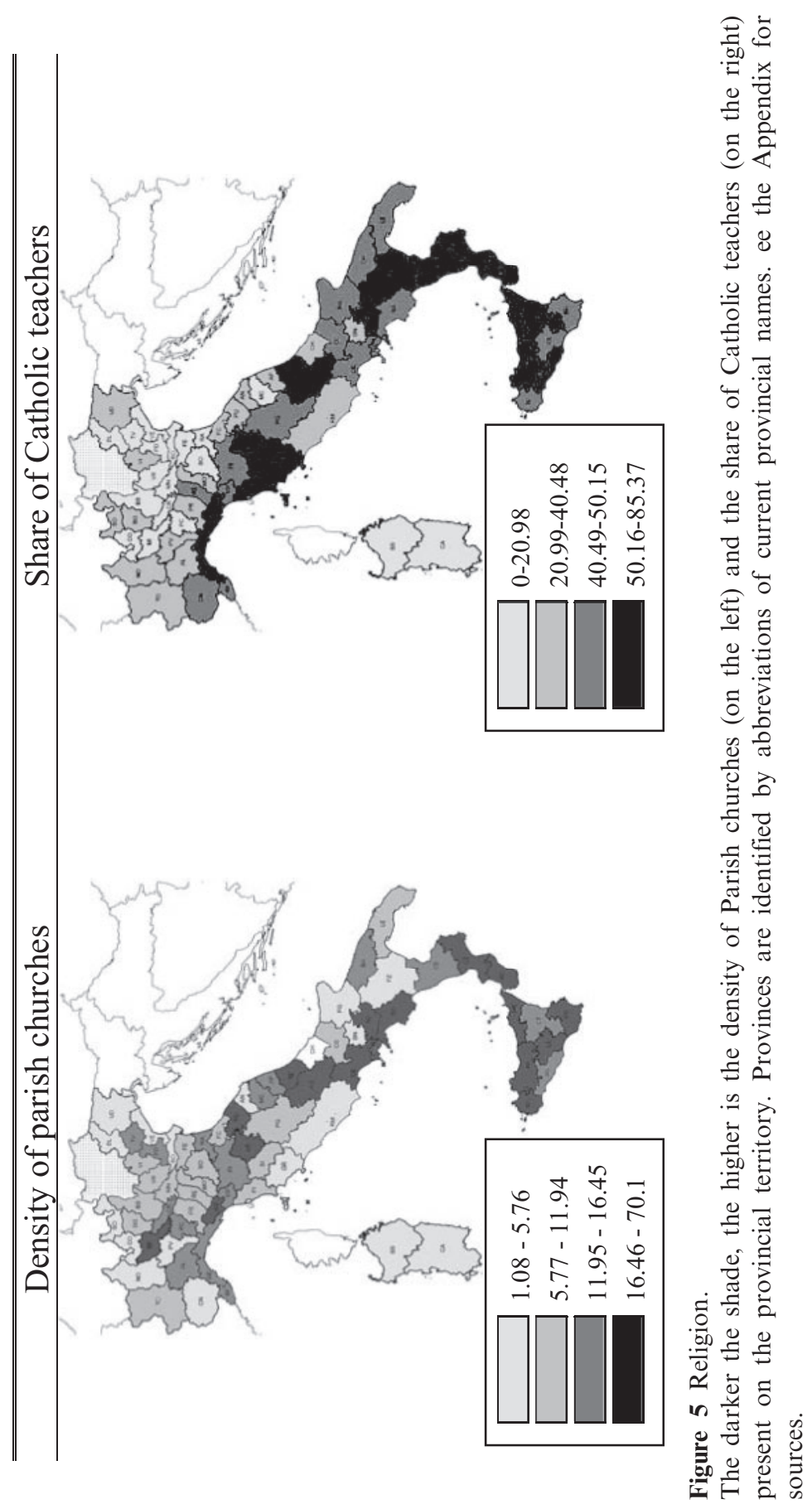




\section{The Historical Education Gender Gap}

In Table 1, we start with a set of Ordinary Least-Square regressions (with clusters at the provincial level) where the dependent variable is the femaleto-male ratio in enrollment rates $^{20}$ at the upper non-compulsory primary level in the 1861-1901 period. To be recalled is that our dependent variable should be interpreted as an index of gender equality in education, so that a positive coefficient indicates that the corresponding regressor is associated with more gender equality and thus a smaller gender gap. In the first column, we assess the effects of economic correlates by entering as regressors, beside time dummies, the 1861-1901 levels of height and industrialization, as proxies of prosperity and structural transformation: their coefficients are both significant and positive, which suggests that economic progress and modernization may indeed be associated with a more favorable position for women in the educational sphere. The (unreported) time dummies also display highly significant and positive coefficients.

In the next columns, we add different sets of regressors, capturing political, religious, and cultural factors. Initially we add one set at a time. In Column 2, we introduce our main indicators for family structure, that is, the dummy for nuclear families and the dummy for partition of inheritance. The former is associated with a more liberal family structure, as opposed to the authoritarian model, which in turn should favor a more advantageous position of women within the family and in society. The latter is associated with more equality among children including females, if compared to alternative customs such as male primogeniture, or discretion, which typically favor male heirs. As suggested by intuition, both indicators are positive and significant.

In Column 3, we insert the set of dummies accounting for the political regimes prevailing before unification. The reference is the Savoy dynasty which until 1861 ruled, roughly, the North West but then took charge of the unified Kingdom of Italy. All the coefficients are negative, suggesting worse performances for the other regimes, even though only the coefficient for the Bourbons is significant, which signals that a deep divide exists from the start between the South and the rest of the country. To be noticed is that controlling for the preunification political regimes means introducing regional fixed effect which non-surprisingly reduce considerably the significance of the economic correlates.

In Columns 4-7, we control for different indicators for religion. The impact of the influence of the Catholic Church is a priori ambiguous. On the one hand, Catholicism is associated with a more traditional role of

20 Enrollment rates are measured as the number of pupils of each gender over the school age (i.e., 6-12 years of age) population of the corresponding gender. 

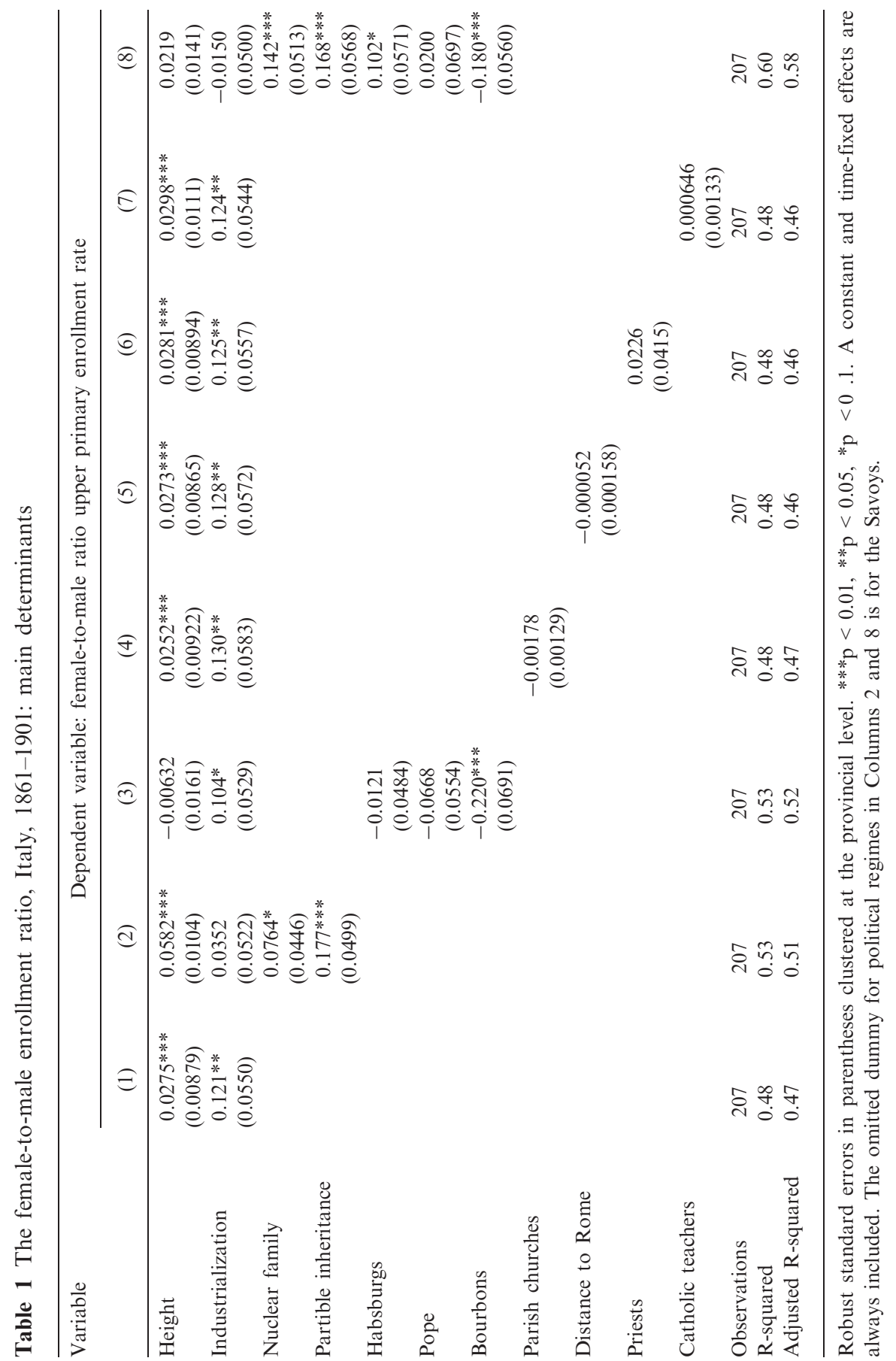
women, which implies a lesser need for them to work and to acquire human capital through education. On the other hand, in the period under examination, education for boys and girls was frequently provided by religious institutions. We capture these factors with four variables: the density of parish churches, distance from Rome, the number of the members of the clergy over population, and the proportion of Catholic teachers. However, when entered one by one, none of them is significant. ${ }^{21}$

The significance of the nuclear family dummy is even larger in a final regression in Column 8 where we enter together all the regressors which are significant in the previous specifications, that is, we also control for political regimes beside economic correlates and time dummies. In this specification, economic correlates are not significant, the inferior performance of the Bourbons is confirmed, and a superior performance emerges for the Habsburgs. The effect of family structure is sizeable, since in this last regression, provinces with a predominance of nuclear families display an over $14 \%$ higher enrollment ratio. In other words, a one-standarddeviation increase of the presence of nuclear families is associated with an increase of 7 percentage points in the female-to-male ratio of the enrollment rate, which is equal to 12.9 percentage points in its sample averages. Moreover, the partial R-square associated with nuclear families suggests that residually they explain $5.6 \%$ of the variation in the residual female-tomale enrollment ratio, conditional on the other controls. Similarly, the presence of partible inheritance implies an almost $17 \%$ higher enrollment ratio, while a one-standard-deviation increase of its presence is associated with an increase of 5.6 percentage points of the dependent (10.3 percentage points in its sample averages) and a partial R-squared of $6.1 \% .{ }^{22}$

Similar results (not reported for brevity) obtain if height is replaced by alternative proxies of prosperity, that is, the 1861-1901 levels of population density and estimates of per capita value added due to Istituto Guglielmo Tagliacarne (2011).

In Table 2, we explore the impact of family structure in further detail. In Column 1, we add to the basic regression with economic correlates and time dummies the proportion of women married before age 15 years. In Column 2, we also add the previous two indicators of family structure. As already anticipated, age at marriage is an important indicator of the degree of subordination of women with respect to men and therefore of gender inequality. We find that early marriage is negatively correlated with relative female enrollment in both specifications, while the coefficient

\footnotetext{
21 Same results are obtained if they are entered together (we omit this specification).

22 In a further specification we also control for geography (latitude, longitude, and plain terrain fraction) which should capture factor endowments, but all dimensions are insignificant and do not affect our results.
} 
Table 2 The female-to-male enrollment ratio, Italy, 1861-1901: further indicators for family structure

\begin{tabular}{|c|c|c|c|c|c|}
\hline \multirow[t]{2}{*}{ Variable } & \multicolumn{5}{|c|}{$\begin{array}{c}\text { Dependent variable: female-to-male ratio upper primary } \\
\text { enrollment rate }\end{array}$} \\
\hline & (1) & (2) & (3) & (4) & (5) \\
\hline Height & $\begin{array}{c}0.0123 \\
(0.0127)\end{array}$ & $\begin{array}{l}0.0432 * * * \\
(0.0127)\end{array}$ & $\begin{array}{l}0.0432 * * * \\
(0.0137)\end{array}$ & $\begin{array}{l}0.0221 \\
(0.0143)\end{array}$ & $\begin{array}{c}0.0205 \\
(0.0143)\end{array}$ \\
\hline Industrialization & $\begin{array}{c}0.138 * * \\
(0.0545)\end{array}$ & $\begin{array}{c}0.0375 \\
(0.0503)\end{array}$ & $\begin{array}{c}0.0142 \\
(0.0471)\end{array}$ & $\begin{array}{r}-0.0159 \\
(0.0512)\end{array}$ & $\begin{array}{c}-0.00885 \\
(0.0501)\end{array}$ \\
\hline Early marriage & $\begin{array}{r}-0.0109^{* *} \\
(0.00525)\end{array}$ & $\begin{array}{l}-0.0140^{* * *} \\
(0.00480)\end{array}$ & & $\begin{array}{c}0.00101 \\
(0.00528)\end{array}$ & \\
\hline Nuclear family & & $\begin{array}{r}0.110^{* *} \\
(0.0455)\end{array}$ & & $\begin{array}{l}0.141^{* * *} \\
(0.0527)\end{array}$ & \\
\hline Partible inheritance & & $\begin{array}{l}0.163^{* * *} \\
(0.0488)\end{array}$ & & $\begin{array}{l}0.167 * * * \\
(0.0568)\end{array}$ & \\
\hline Egal. nucl. family early marriage & & & $\begin{array}{l}-0.139^{* * *} \\
(0.0502)\end{array}$ & & $\begin{array}{l}0.121 \\
(0.0853)\end{array}$ \\
\hline Incomplete stem family & & & $\begin{array}{l}-0.282^{* * *} \\
(0.0546)\end{array}$ & & $\begin{array}{l}-0.279^{* * *} \\
(0.0666)\end{array}$ \\
\hline Communitarian family & & & $\begin{array}{l}-0.136^{* * *} \\
(0.0459)\end{array}$ & & $\begin{array}{c}-0.0932 \\
(0.0727)\end{array}$ \\
\hline Habsburgs & & & & $\begin{array}{c}0.102 * \\
(0.0572)\end{array}$ & $\begin{array}{c}0.0759 \\
(0.0619)\end{array}$ \\
\hline Pope & & & & $\begin{array}{c}0.0202 \\
(0.0698)\end{array}$ & $\begin{array}{c}-0.0322 \\
(0.0850)\end{array}$ \\
\hline Bourbons & & & & $\begin{array}{c}-0.186^{* * *} \\
(0.0649)\end{array}$ & $\begin{array}{c}-0.296^{* * *} \\
(0.100)\end{array}$ \\
\hline Observations & 207 & 207 & 207 & 207 & 207 \\
\hline$R^{2}$ & 0.49 & 0.55 & 0.55 & 0.60 & 0.60 \\
\hline Adjusted $R^{2}$ & 0.48 & 0.53 & 0.54 & 0.58 & 0.58 \\
\hline
\end{tabular}

Robust standard errors in parentheses clustered at the provincial level. ***p $<0.01$, ${ }^{* *} \mathrm{p}<0.05,{ }^{*} \mathrm{p}<0.1$. A constant and time-fixed effects are always included. The omitted dummies are the egalitarian nuclear family with late marriage in Columns 3 and 5 and the Savoys for political regimes in Columns 4 and 5 .

for nuclear family is now larger and more precisely measured. In Column 3, we insert the three family dummies inspired by the Todd (1990) classification, augmented to account for differential female age at marriage within nuclear families. The omitted dummy is the one for the egalitarian nuclear family with late female age at marriage. The coefficients for the egalitarian nuclear family with early marriage, the communitarian family, and the incomplete stem family are all significantly negative. However, when in Column 4 we also add political regimes to reproduce the extended specification in Table 1, Column 8, the additional explanatory power of 
marriage age disappears, while the other two dimensions capturing residential and inheritance patterns are confirmed as significant (to be recalled, however, is that the variable reflecting age is measured at the regional rather than provincial level). Similarly, in the extended specification in Column 5, only the incomplete stem family - which involves complex residential habits as well as de facto primogeniture - retains an explanatory power, possibly because of the partial overlap between political regimes and prevailing family structures. This exercise confirms that the two separate dimensions we choose to emphasize from the start not only display a more robust influence but also allow a more precise assessment of which is the channel through which family structure exerts its influence.

We also obtain very similar results in Table 3 if we replace the dependent variable with the enrollment ration at the aggregate primary level. In Column 1 (the analogue of Column 8 of Table 1), the coefficient of nuclear family is less significant. The same occurs in Column 2 if compared with Column 4 of Table 2. In Column 3, if compared with Column 5 of Table 2, we observe a loss of significance for the coefficient of the egalitarian nuclear family with early marriage. These differences are not surprising since the upper level is non-compulsory and therefore more likely to reflect individual choices, while at the lower level and at the aggregate we should expect less variability in all the relevant dimensions. Moreover, a trace of the effect of religion emerges at the lower level (unreported for brevity), where the presence of the clergy becomes beneficial for relative female enrollment, even though this result should be taken with caution since this variable is measured at the regional rather than provincial level.

In Table 4, we try to evaluate whether the influence of family structure varies throughout the period under consideration, by adding to the extended specification of Table 1, Column 8, a set of interactions between time and each of the two indicators for residential patterns and inheritance rules. The fact that the interactions are not significant and the positive coefficient is retained for both indicators confirms that the influence of our focal variables is stable throughout the historical period under investigation (for instance, a negative coefficient for the interactions would instead suggest that the effect is declining through time).

We can therefore conclude that, over the first four decades after unification, economic and religious factors are not exerting a significant influence on the education gender gap, geopolitical factors do so but only marginally, while nuclear residential patterns and equal inheritance rules are strongly and persistently associated with a lower gap. Even though we should be cautious in interpreting our results as causal, the evidence we present is robust across different specifications. 
Table 3 The female-to-male enrollment ratio, Italy, 1861-1901: the aggregate primary level

Variable

Dependent variable: female-to-male enrollment ratio

(1)

(2)

(3)

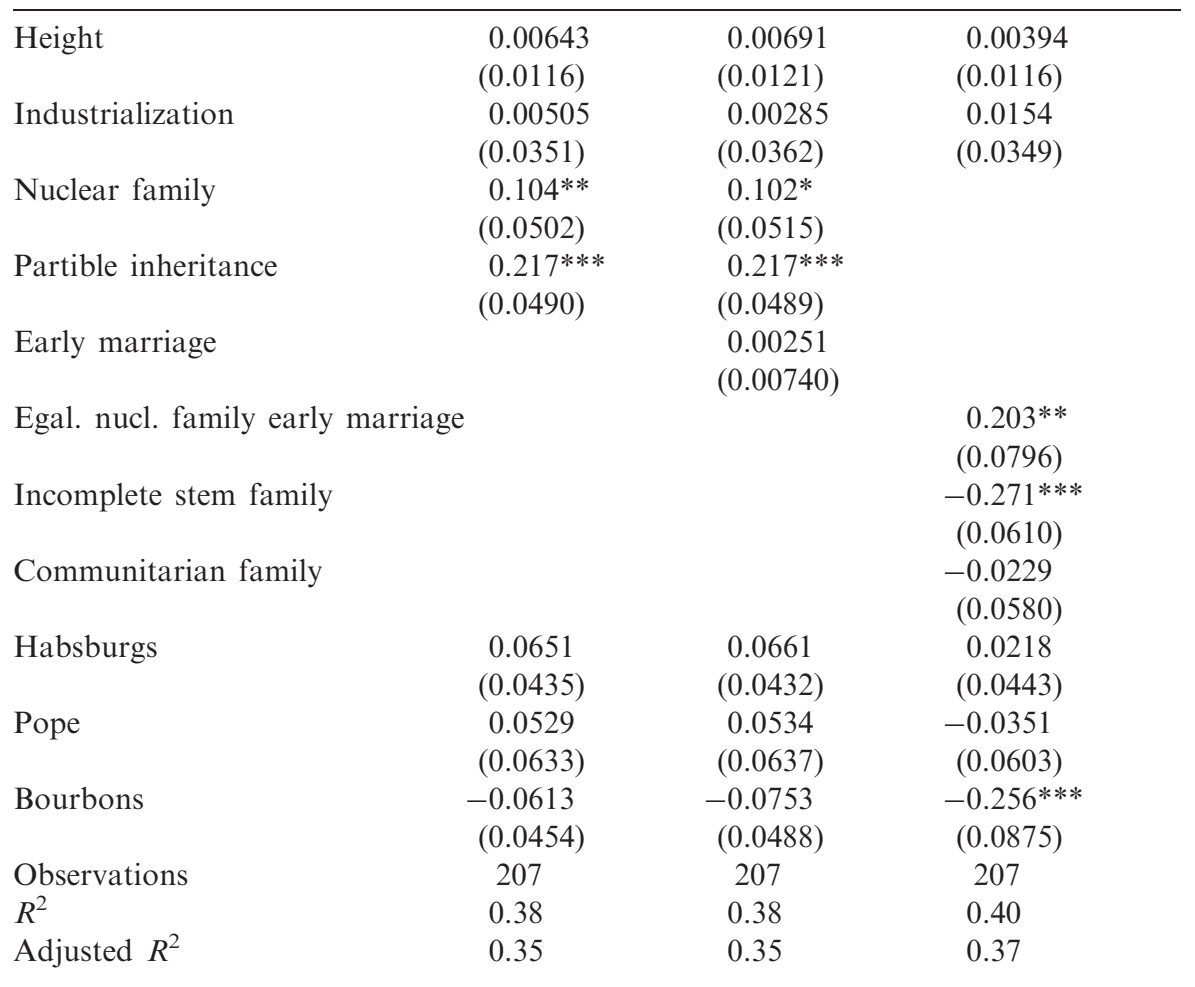

Robust standard errors in parentheses clustered at the provincial level. $* * * p<0.01$, ${ }^{* *} \mathrm{p}<0.05,{ }^{*} \mathrm{p}<0.1$. A constant and time-fixed effects are always included. The omitted dummies are the egalitarian nuclear family with late marriage in Column 3 and the Savoys for political regimes.

\section{The Contemporaneous Education Gender Gap}

In this section, we investigate the long-term persistence of the effect of family structure on contemporaneous measures of the education gender gap. Since gender equality at the primary level is a well-established fact in post-World War II Italy, we focus on higher educational levels, that is, secondary and tertiary levels. The position of females at both levels, as of 1971 , is far from equal from that of males, especially at the tertiary level. 
Table 4 The female-to-male enrollment ratio, Italy, 1861-1901: dynamics

\begin{tabular}{|c|c|}
\hline Variable & $\begin{array}{l}\text { Dependent variable: } \\
\text { female-to-male upper primary } \\
\text { enrollment rate } \\
\text { (1) }\end{array}$ \\
\hline Height & $\begin{array}{c}0.0223^{*} \\
(0.0116)\end{array}$ \\
\hline Industrialization & $\begin{array}{c}-0.0147 \\
(0.0447)\end{array}$ \\
\hline Nuclear family & $\begin{array}{c}0.181 * * \\
(0.0812)\end{array}$ \\
\hline Partible inheritance & $\begin{array}{c}0.161 * \\
(0.0848)\end{array}$ \\
\hline Habsburgs & $\begin{array}{c}0.101 * * \\
(0.0501)\end{array}$ \\
\hline Pope & $\begin{array}{c}0.0200 \\
(0.0595)\end{array}$ \\
\hline Bourbons & $\begin{array}{c}-0.179 * * * \\
(0.0456)\end{array}$ \\
\hline Nuclear*1881 & $\begin{array}{c}-0.0940 \\
(0.0788)\end{array}$ \\
\hline Nuclear*1901 & $\begin{array}{c}-0.0233 \\
(0.0745)\end{array}$ \\
\hline Partible inheritance*1881 & $\begin{array}{c}-0.00795 \\
(0.0855)\end{array}$ \\
\hline Partible inheritance*1901 & $\begin{array}{c}0.0273 \\
(0.0809)\end{array}$ \\
\hline Observations & 207 \\
\hline$R^{2}$ & 0.61 \\
\hline Adjusted $R^{2}$ & 0.58 \\
\hline
\end{tabular}

Robust standard errors in parentheses clustered at the provincial level. $* * * p<0.01$, $* * p<0.05, * p<0.1$. A constant and time-fixed effects are always included. The omitted dummy for political regimes is for the Savoys.

The picture changes sensibly in 2001, with a near-closing of the gap at both levels, and in fact almost perfect equality at the tertiary level, which suggests the interplay of different and level-specific factors in explaining the gap and its evolution. Within this contemporaneous dataset, family structure is measured again as within the previous historical dataset since, even though it is true that it has evolved, we aim at capturing its long-term influence, while avoiding at the same time likely endogeneity problems which would be associated with updated contemporaneous measures. 
A direct comparison with previous results derived on the basis of the 1861-1901 sample is in order. First of all, flow data for enrollments are not available at the provincial level for the contemporaneous sample, so we can only use stock data reflecting the number of females over the number of males with a specific degree. Moreover, we treat 1971 and 2001 data as cross sections, rather than pooling them as in the 1861-1901 sample.

Keeping in mind the above caveats, in Table 5 we present our results, for a specification which includes, for each year, the corresponding income level, the variables reflecting family structure, and dummies for the macroregions that reflect the current political geography of Italy (with the North West, roughly corresponding to the Savoys' territories, as a reference). Column 1 shows that partible inheritance is positively associated with relative female attainment at the secondary level in 1971, while the presence of nuclear families no longer matters. ${ }^{23}$ The same conclusion can be reached for the tertiary level in the same year and again for the secondary and tertiary in 2001 (Columns 3, 5, and 7).

When we turn to the set of family dummies we find that, relative to the egalitarian nuclear family with late marriage, the coefficient of the egalitarian nuclear with early marriage is significantly negative in three of four regressions, while that of the communitarian family is positive for the secondary level in 1971. Taken together, these results are quite different from those emerging from the historical measures of the gender gap, and even harder to interpret.

To sum up, over the long run a single dimension of family structure, the one reflecting equality in inheritance rule, exerts a persistent influence on the gender gap in education, while residential patterns no longer matter, suggesting that historical legacies may show different degrees of persistence. $^{24}$

\section{Conclusion}

The first achievement of this article is to adapt existing classifications of family structure to the specific historical circumstances prevailing in Italy at least since the 19th century. The second achievement of the article is to show that family structure exhibits significant variation across Italian provinces, despite the fact that in cross-sectional studies the country is often viewed as homogenous in this respect. Finally, the article shows

23 In their analysis of contemporaneous welfare systems Galasso and Profeta (2013) also find an impact of partible inheritance but not of residential habits.

24 Similar results are obtained when data for 1971 and 2001 are pooled. 
Family Structure and the Education Gender Gap

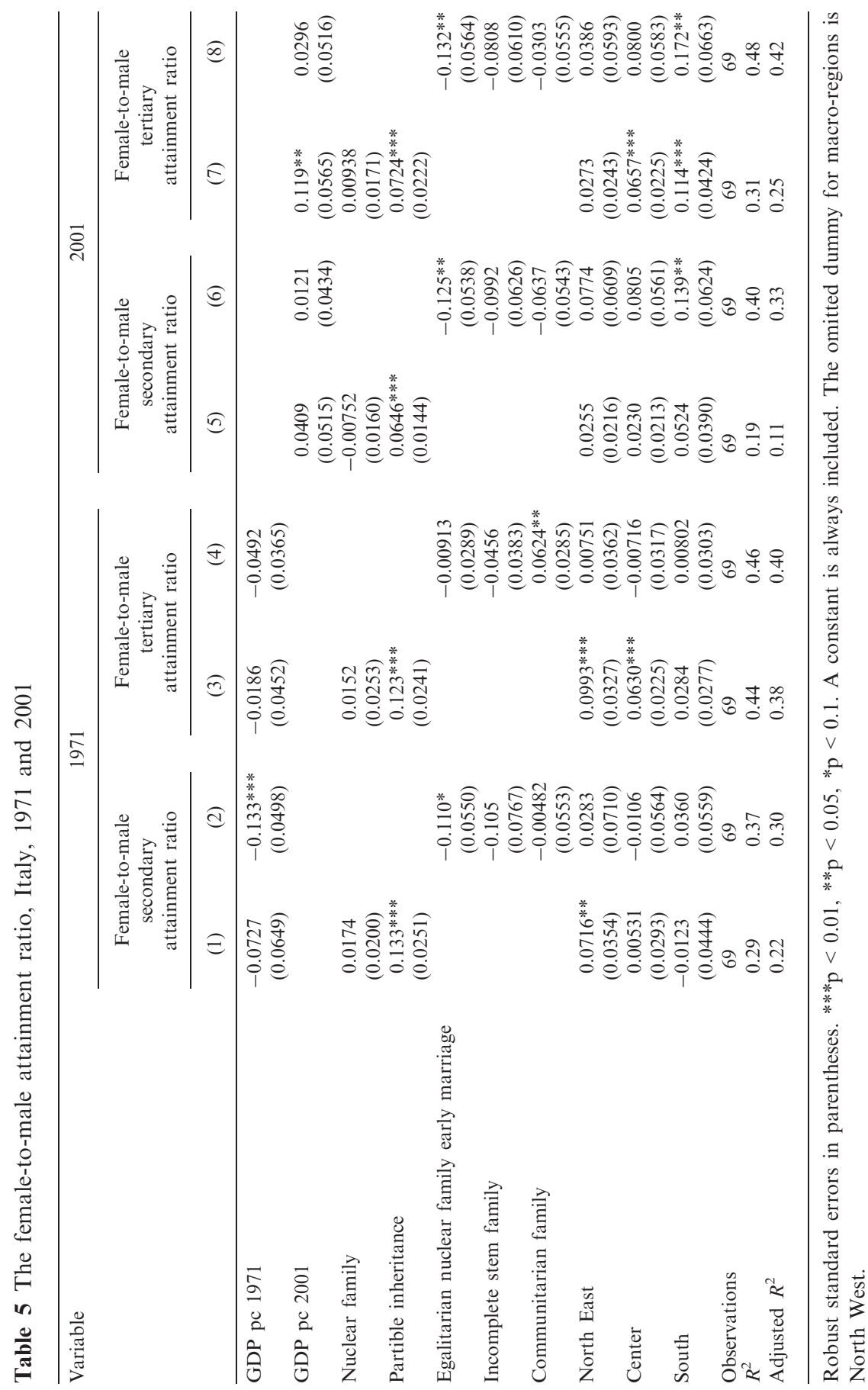

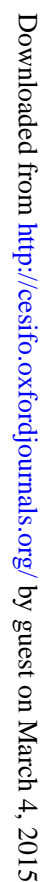


that family structure affects the gender gap in education in a lasting fashion, even after controlling for a rich set of correlates reflecting economic performances, the political geography of the country prior to unification, and the influence of the Catholic Church. However, the influence of family structure varies if we compare our historical (1861-1901) sample with the contemporaneous (1971-2001) one. While over the historical sample both nuclear residential patterns and equal inheritance rules are strongly associated with more gender equality in education, over the contemporaneous sample only the latter still exert a persistent influence.

Over a century and a half after the unification of Italy in 1861, the education gender gap has been gradually closing, and even reversing in recent years, following a pattern which is common to most developed countries. As women's lives have been transformed thanks to the improvement of their educational attainment together with their economic and social position, the structure of the family inherited from history has also been transformed, with a rapid decline of marriage and a drastic reduction of fertility. To understand how family structure and the gender gap are jointly evolving within a dynamic theoretical model is the next challenge for future research.

\section{Acknowledgements}

The authors would like to thank Paola Giuliano, Katharina Jaronicki, Paola Profeta, two anonymous referees, and participants at the CESifo Venice Summer Institute Workshop on The Determinants of Gender Gaps: Institutional Design and Historical Factors, for helpful comments. Generous financial support from Fondazione Cassa Risparmio di Modena and the Italian University Ministry is gratefully acknowledged.

\section{References}

A'Hearn, B., C. Auria, G. and Vecchi (2011), "Istruzione", in G. Vecchi, ed. Ricchezza e in Povertà: Il Benessere degli Italiani dall'Unità a Oggi, Il Mulino, Bologna, pp. 159-206.

A'Hearn, B., F. Peracchi and G. Vecchi (2009), "Height and the Normal Distribution: Evidence from Italian Military Data", Demography 46, 1-25.

Alesina, A. F. and P. Giuliano (2010), "The Power of the Family", Journal of Economic Growth 15, 93-125.

Alesina, A. F. and P. Giuliano (2014), "Family Ties", in P. Aghion and S. Durlauf, eds., Handbook of Economic Growth, vol. 2, North Holland, Oxford, pp. 177-215. 
Alesina, A. F., P. Giuliano and N. Nunn (2013), "On the Origins of Gender Roles: Women and the Plough", Quarterly Journal of Economics 128, 469-530.

Algan, Y. and P. Cahuc (2006), "Job Protection: The Macho Hypothesis", Oxford Review of Economic Policy 22, 390-410.

Amati, A. (1860), Elementi di Geografia dell'Italia, con Cenni Storici e Statistici, G. Gnocchi Editore-Libraio, Milan.

Banfield, E. (1958), The Moral Basis of a Backward Society, Free Press, New York.

Barbagli, M. (1987), "Sistemi di Formazione della Famiglia in Italia", Bollettino di Demografia Storica 2, 80-127.

Becker, G.F. and R. J. Barro (1988), "A Reformulation of the Economic Theory of Fertility", Quarterly Journal of Economics 103, 1-25.

Becker, S. O. and L. Wößmann (2008), "Luther and the Girls: Religious Denomination and the Female Education Gap in Nineteenth-century Prussia”, Scandinavian Journal of Economics 110, 777-805.

Becker, S. O. and L. Wößmann (2009), "Was Weber Wrong? A Human Capital Theory of Protestant Economic History", Quarterly Journal of Economics 124, 531-96.

Benavot, A. and P. Riddle (1988), "The Expansion of Primary Education, 1870-1940: Trends and Issues”, Sociology of Education 61, 191-210.

Bertocchi, G. (2006), "The Law of Primogeniture and the Transition from Landed Aristocracy to Industrial Democracy", Journal of Economic Growth 11, 41-68.

Bertocchi, G. (2011), "The Enfranchisement of Women and the Welfare State", European Economic Review 55, 535-53.

Bertocchi, G. and M. Bozzano (2013), "Women, Medieval Commerce, and the Education Gender Gap", CEPR Discussion Paper No. 9359, Center for Economic Policy Research, London.

Bertocchi, G., M. Brunetti and C. Torricelli (2014), "Is It Money or Brains? The Determinants of Intra-Family Decision Power", Journal of Economic Behavior and Organization 101, 65-86.

Bertocchi, G. and M. Spagat (1997), "Il Ruolo dei Licei e delle Scuole Tecnico-Professionali tra Progresso Tecnologico, Conflitto Sociale e Sviluppo Economico", in N. Rossi, ed. L'Istruzione in Italia: Solo un Pezzo di Carta?, Il Mulino, Bologna, pp. 421-59.

Bertola, G. and P. Sestito (2013), "Human Capital”, in G. Toniolo, ed. The Oxford Handbook of the Italian Economy since Unification, Oxford University Press, New York, pp. 249-70. 
Bloch, M. (1949), Apologie pour l'Histoire ou Métier d'Historien, Librairie Armand Colin, Paris.

Bianchi, M. (1845), Geografia Politica dell'Italia, Società Editrice Fiorentina, Florence.

Bozzano, M. (2014), “Assessing Gender Inequality among Italian Regions: The Italian Gender Gap Index", Rivista di Politica Economica 103, 255-300.

Buonazia, G. (1870), Documenti sulla Istruzione Elementare del Regno d'Italia, Parte II, Eredi Botta, Florence.

Ciccarelli, C. and S. Fenoaltea (2013), "Through the Magnifying Glass: Provincial Aspects of Industrial Growth in Post-Unification Italy", Economic History Review 66, 57-85.

Coleman, J. S. (1990), Foundations of Social Theory, Harvard University Press, Cambridge.

Correnti, C. (1858), Annuario Statistico Italiano. Anno I: 1857-58, Tipografia Letteraria, Turin.

Del Panta, L., M. Livi Bacci and G. Pinto (1996), La Popolazione Italiana dal Medioevo a Oggi, Laterza, Rome.

De Mauro, T. (1963), Storia Linguistica dell'Italia Unita, Laterza, Bari.

De Moor, T. and J. L. Van Zanden (2010), “Girlpower: The European Marriage Pattern and Labour Markets in the North Sea Region in the Late Medieval and Early Modern Period”, Economic History Review 63, $1-33$.

Dennison, T. and S. Ogilvie (2013), "Does the European Marriage Pattern Explain Economic Growth?", CESifo Working Paper No. 4244, CESifo, Munich.

Dilli, S., A. Rijpma and S. Carmichael (2013), "Development Versus Legacy: The Relative Role of Development and Historical Legacies in Achieving Gender Equality", CESifo Working Paper No. 4411, CESifo, Munich.

DIRSTAT (1877), Popolazione. Movimento dello Stato Civile. Anno 1875, Tipografia Cenniniana, Rome.

Duflo, E. (2012), "Women Empowerment and Economic Development", Journal of Economic Literature 50, 1051-79.

Duranton, G., A. Rodriguez-Pose and R. Sandall (2009), "Family Types and the Persistence of Regional Disparities in Europe", Economic Geography 85, 23-47.

Esping-Andersen, G. (1990), The Three Worlds of Welfare Capitalism, Cambridge University Press, Cambridge. 
Fernandez, R. and J. C. Wong (2011), The Disappearing Gender Gap: The Impact of Divorce, Wages, and Preferences on Education Choices and Women's Work, Mimeo, New York University.

Fogel, R. W., S. L. Engerman and J. Trussell (1982), "Exploring the Uses of Data on Height: The Analysis of Long-Term Trends in Nutrition, Labor Welfare, and Labor Productivity", Social Science History 6, 401-21.

Foreman-Peck, J. (2011), "The Western European Marriage Pattern and Economic Development", Explorations in Economic History 48, 292-309.

Galasso, V. and P. Profeta (2010), "When the State Mirrors the Family: The Design of Pension Systems", CEPR Discussion Papers No. 8723, Center for Economic Policy Research, London.

Galasso, V. and P. Profeta (2013), From Family Culture to Welfare State Design, Bocconi University, Mimeo.

Galor, O. and D. N. Weil (1996), "The Gender Gap, Fertility, and Growth", American Economic Review 86, 374-87.

Goldin, C. (1998), "America's Graduation from High School: The Evolution and Spread of Secondary Schooling in the Twentieth Century", Journal of Economic History 58, 345-74.

Goldin, C., L. F. Katz and I. Kuziemko (2006), "The Homecoming of American College Women: The Reversal of the Gender Gap in College", Journal of Economic Perspectives 20, 133-56.

Goody, J. (1976), "Inheritance, Property and Women: Some Comparative Considerations", in J. Goody, J. Thirsk and E. P. Thompson, eds., Family and Inheritance: Rural Society in Western Europe 1200-1800, Cambridge University Press, Cambridge, pp. 10-36.

Greif, A. and G. Tabellini (2012), The Clan and the City: Sustaining Cooperation in China and Europe, Stanford University, Mimeo.

Hajnal, J. (1965), "European Marriage Patterns in Perspective", in D. V. Glass and D. E. C. Eversley, eds., Population in History: Essays in Historical Demography, Edward Arnold, London, pp. 101-143.

Hajnal, J. (1982), "Two Kinds of Preindustrial Household Formation System", Population and Development Review 8, 449-94.

Incatasciato, B. (1978), "Leggere, Scrivere, Far di Conto. Per una Storia della Didattica nella Scuola Elementare", in T. Tomasi, G. Genovesi, M. P. Tancredi Torelli, B. Incatasciato, S. Ulivieri and E. Catarsi, eds., L'Istruzione di Base in Italia (1859-1977), Vallecchi, Florence, pp. 128-34. 
ISTAT (2009), Atlante Statistico dei Comuni. Settore Ambiente e Territorio, Istituto Nazionale di Statistica, Rome.

Istituto Guglielmo Tagliacarne (2011), Reddito e Occupazione nelle Province Italiane dal 1861 ad Oggi, Istituto Guglielmo Tagliacarne, Rome.

Licini, S. (2011), "Assessing Female Wealth in Nineteenth Century Milano, Italy", Accounting History 16, 35-54.

MAIC (1864), Popolazione: Censimento Generale (31 Dicembre 1861), Tipografia Letteraria, Turin.

MAIC (1865), Statistica del Regno d'Italia. Istruzione Pubblica e Privata. Anno Scolastico 1862-63, Enrico Dalmazzo Tipografo, Turin.

MAIC (1868), Statistica del Regno d'Italia, Popolazione, Movimento dello Stato Civile del 1867, Tipografia Tofani, Florence.

MAIC (1872), Censimento della Popolazione del Regno d'Italia al 31 Dicembre 1871, Stamperia Reale, Rome.

MAIC (1874), Annuario della Istruzione Pubblica del Regno d'Italia per l'Anno Scolastico 1873-74, Regia Tipografia, Rome.

MAIC (1883), Censimento della Popolazione del Regno d'Italia al 31 Dicembre 1881, Tipografia Bodoniana, Rome.

MAIC (1884), Statistica della Istruzione Primaria e Normale per l'Anno Scolastico 1881-82, Tipografia Nazionale, Rome.

MAIC (1902), Censimento della Popolazione del Regno d'Italia al 10 Febbraio 1901, Tipografia Nazionale Bertero, Rome.

MAIC (1906), Statistica della Istruzione Primaria e Normale per l'Anno Scolastico 1901-02, Tipografia Nazionale Bertero, Rome.

Palmieri, A. (1857), Topografia Statistica dello Stato Pontificio. Parte Prima, Roma, Tipografia Forense, Rome.

Pécout, G. (1999), Il Lungo Risorgimento: La Nascita dell'Italia Contemporanea (1770-1922), Edizioni Bruno Mondadori, Milan.

Sacchi, G. (1858), Le Scuole Reali Inferiori ed Elementari nelle Provincie Venete, Annali Universali di Statistica, Economia Pubblica, Legislazione, Storia, Viaggi e Commercio No. 133.

Serristori, L. (1842), Statistica dell'Italia, Stamperia Granducale, Florence.

Spolaore, E. and R. Wacziarg (2013), "How Deep Are the Roots of Economic Development?", Journal of Economic Literature 51, 325-69.

Todd, E. (1984), L'Enfance du Monde, Structures Familiales et Développement, Seuil, Paris. 
Todd, E. (1990), L'Invention de l'Europe, Seuil, Paris.

Tur-Prats, A. (2014), Family Types and Intimate-Partner Violence: A Historical Perspective, Mimeo. Universitat Autonoma de Barcelona.

Vigo, G. (1971), Istruzione e Sviluppo Economico in Italia nel Secolo XIX, Archivio Economico dell'Unificazione Italiana, Serie II, vol. XVIII. ILTE, Turin.

Voigtlander, N. and H. J. Voth (2013), "How the West "Invented" Fertility Restriction", American Economic Review 103, 2227-64.

Zamagni, V. (2002), "L'Offerta di Istruzione in Italia 1861-1981: Un Fattore Guida dello Sviluppo o un Ostacolo?", in G. Gilli, M. Lupo and I. Zilli, eds., Scuola e Società. Le Istituzioni Scolastiche in Italia dall'Età Moderna al Futuro, ESI, Naples, pp. 143-182.

\section{APPENDIX}

This appendix describes the data underlying our study in more detail. The dataset contains information from 69 Italian provinces at 1871 boundaries. We collect province-level data at three points in time (1861, 1881, 1901) whenever available, spanning the first 40 years after Italian unification. For the post-World War II period we collect data for 1971 and 2001. Table A1 contains variable definitions and sources. Methodological notes on the construction of the dataset follow next. Table A2 presents summary statistics.

\section{Methodological Notes}

Historical education data: We collect data for 1861, 1881, and 1901. Due to historical circumstances, we encountered a few problems because of lack of data in particular referring to the first wave. This arises from the fact that the Italian unification process was a gradual process, and therefore official statistical annuals could not take into account those provinces which entered the Italian Kingdom only in subsequent years. As a result, data on gross enrollments (that is, number of pupils of any age who are enrolled in primary schools as a percentage of the total official school-age children) are constructed from various sources and mainly from Statistica del Regno d'Italia, Istruzione pubblica e privata, a statistical series compiled and published by the Ministry of Agriculture, Industry and Commerce (MAIC) from 1865 to 1906, and from Vigo (1971). For most provinces, we impute to 1861 enrollment data referring 
Table A1. Variable definitions and sources

\begin{tabular}{|c|c|c|}
\hline Variable & Construction & Main source \\
\hline Primary enrollment rate & $\begin{array}{l}\text { Pupils enrolled in primary school/ } \\
\text { population of primary school age } \\
(6-12) * 100\end{array}$ & MAIC (various years) \\
\hline $\begin{array}{l}\text { Lower primary enrollment } \\
\text { rate }\end{array}$ & $\begin{array}{l}\text { Pupils enrolled in lower primary } \\
\text { school/ population of primary } \\
\text { school age }(6-12) * 100\end{array}$ & MAIC (various years) \\
\hline $\begin{array}{l}\text { Upper primary enrollment } \\
\text { rate }\end{array}$ & $\begin{array}{l}\text { Pupils enrolled in upper primary } \\
\text { school/ population of primary } \\
\text { school age }(6-12) * 100\end{array}$ & MAIC (various years) \\
\hline Male primary enrollment rate & $\begin{array}{l}\text { Male pupils enrolled in primary } \\
\text { school/ male population of pri- } \\
\text { mary school age }(6-12) * 100\end{array}$ & MAIC (various years) \\
\hline $\begin{array}{l}\text { Female primary enrollment } \\
\text { rate }\end{array}$ & $\begin{array}{l}\text { Female pupils enrolled in primary } \\
\text { school/ female population of pri- } \\
\text { mary school age }(6-12) * 100\end{array}$ & MAIC (various years) \\
\hline $\begin{array}{l}\text { Female to male primary en- } \\
\text { rollment ratio }\end{array}$ & $\begin{array}{l}\text { [Female pupils enrolled in primary } \\
\text { school/ female population of pri- } \\
\text { mary school age }(6-12)] /[\text { male } \\
\text { pupils enrolled in primary school/ } \\
\text { male population of primary } \\
\text { school age }(6-12)]=\text { female pupils } \\
\text { enrolled in primary school/ male } \\
\text { pupils enrolled in primary school } \\
\text { * masculinity of primary school } \\
\text { age }(6-12) \text { population }\end{array}$ & MAIC (various years) \\
\hline $\begin{array}{l}\text { Female to male upper pri- } \\
\text { mary enrollment ratio }\end{array}$ & $\begin{array}{l}\text { Female pupils enrolled in upper pri- } \\
\text { mary school/ male pupils enrolled } \\
\text { in upper primary school * mas- } \\
\text { culinity of primary school age }(6- \\
\text { 12) population }\end{array}$ & MAIC (various years) \\
\hline $\begin{array}{l}\text { Female to male lower pri- } \\
\text { mary enrollment ratio }\end{array}$ & $\begin{array}{l}\text { Female pupils enrolled in lower pri- } \\
\text { mary school/ male pupils enrolled } \\
\text { in lower primary school * mascu- } \\
\text { linity of primary school age }(6-12) \\
\text { population }\end{array}$ & MAIC (various years) \\
\hline $\begin{array}{l}\text { Female to male secondary } \\
\text { attainment ratio } 1971\end{array}$ & $\begin{array}{l}\text { Females with at least a high school } \\
\text { diploma/ males with at least a } \\
\text { high-school diploma. Year } 1971 \text {. }\end{array}$ & ISTAT (2009) \\
\hline $\begin{array}{l}\text { Female to male tertiary at- } \\
\text { tainment ratio } 1971\end{array}$ & $\begin{array}{l}\text { Females with a university degree/ } \\
\text { males with a university degree. } \\
\text { Year } 1971 .\end{array}$ & ISTAT (2009) \\
\hline $\begin{array}{l}\text { Female to male secondary } \\
\text { attainment ratio } 2001\end{array}$ & $\begin{array}{l}\text { Females with at least a high school } \\
\text { diploma over female population } \\
\text { over age } 19 / \text { males with at least a } \\
\text { high school diploma over male } \\
\text { population over age } 19 \text {. Year } \\
\text { 2001. }\end{array}$ & ISTAT (2009) \\
\hline $\begin{array}{l}\text { Female to male tertiary at- } \\
\text { tainment ratio } 2001\end{array}$ & $\begin{array}{l}\text { Females with a university degree } \\
\text { over female population over age } \\
\text { 19/ males with a university degree }\end{array}$ & ISTAT (2009) \\
\hline
\end{tabular}


Table A1. Continued

\begin{tabular}{|c|c|c|}
\hline Variable & Construction & Main source \\
\hline & $\begin{array}{l}\text { over male population over age } 19 . \\
\text { Year } 2001 \text {. }\end{array}$ & \\
\hline Masculinity & $\begin{array}{l}\text { Male population of primary school } \\
\text { age }(6-12) / \text { female population of } \\
\text { primary school age }(6-12)\end{array}$ & Census (various years) \\
\hline Latitude & $\begin{array}{l}\text { Latitude of the main city of the } \\
\text { province in decimal degrees. }\end{array}$ & Passim \\
\hline Longitude & $\begin{array}{l}\text { Longitude of the main city of the } \\
\text { province in decimal degrees. }\end{array}$ & Passim \\
\hline Plain terrain & $\begin{array}{l}\text { Percentage of plain terrain over the } \\
\text { total surface of the province }\end{array}$ & Passim \\
\hline Distance from Rome & $\begin{array}{l}\text { Distance of the main provincial city } \\
\text { or town to Rome, in kilometers } \\
\text { (great-circle distance). }\end{array}$ & $\begin{array}{l}\text { http://distanzechilome- } \\
\text { triche.net }\end{array}$ \\
\hline Clergy & $\begin{array}{l}\text { Number of clergy members/ } 100 \text { in- } \\
\text { dividuals in population, in year } \\
1857 \text { (at the regional level) }\end{array}$ & $\begin{array}{l}\text { Amati (1860), Correnti } \\
\quad(1858)\end{array}$ \\
\hline Parish churches & $\begin{array}{l}\text { Number of parish churches in exist- } \\
\text { ence in the } 1840-50 \text { s/ provincial } \\
\text { surface in squared kilometers. }\end{array}$ & $\begin{array}{l}\text { Bianchi (1845), Palmieri } \\
\quad \text { (1857) }\end{array}$ \\
\hline Catholic teachers & $\begin{array}{l}\text { Number of Catholic teachers/ total } \\
\text { number of teachers, in year } 1862\end{array}$ & MAIC $(1865,1874)$ \\
\hline Nuclear family & $\begin{array}{l}\text { Dummy variable: } 1 \text { if the nuclear } \\
\text { family type prevails, } 0 \text { otherwise }\end{array}$ & Todd (1990) \\
\hline Partible inheritance & $\begin{array}{l}\text { Dummy variable: } 1 \text { if the partible } \\
\text { inheritance rule prevails, } 0 \\
\text { otherwise }\end{array}$ & Todd (1990) \\
\hline Early marriage & $\begin{array}{l}\text { Women below age } 15 / \text { married } \\
\text { women, in } 1872-1875 \text { (at the re- } \\
\text { gional level) }\end{array}$ & $\begin{array}{l}\text { Barbagli (1987), } \\
\text { DIRSTAT (1877) }\end{array}$ \\
\hline $\begin{array}{l}\text { Egalitarian nuclear family } \\
\text { with early marriage }\end{array}$ & $\begin{array}{l}\text { Dummy variable: } 1 \text { if the } \\
\text { egalitarian nuclear family type } \\
\text { with early marriage prevails, } 0 \\
\text { otherwise }\end{array}$ & $\begin{array}{l}\text { Todd (1990), Del Panta } \\
\text { et al. (1996) }\end{array}$ \\
\hline $\begin{array}{l}\text { Egalitarian nuclear family } \\
\text { with late marriage }\end{array}$ & $\begin{array}{l}\text { Dummy variable: } 1 \text { if the } \\
\text { egalitarian nuclear family type } \\
\text { with late marriage prevails, } 0 \\
\text { otherwise }\end{array}$ & $\begin{array}{l}\text { Todd (1990), Del Panta } \\
\text { et al. (1996) }\end{array}$ \\
\hline Incomplete stem family & $\begin{array}{l}\text { Dummy variable: } 1 \text { if the incomplete } \\
\text { stem family type prevails, } 0 \\
\text { otherwise }\end{array}$ & $\begin{array}{l}\text { Todd (1990), Del Panta } \\
\text { et al. (1996) }\end{array}$ \\
\hline Communitarian family & $\begin{array}{l}\text { Dummy variable: } 1 \text { if the communi- } \\
\text { tarian family type prevails, } 0 \\
\text { otherwise }\end{array}$ & $\begin{array}{l}\text { Todd (1990), Del Panta } \\
\text { et al. (1996) }\end{array}$ \\
\hline Savoys & $\begin{array}{l}\text { Dummy variable: } 1 \text { if the province } \\
\text { was ruled by the Savoy-Carignano } \\
\text { dynasty prior to unification, } 0 \\
\text { otherwise }\end{array}$ & Pécout (1999) \\
\hline Habsburgs & $\begin{array}{l}\text { Dummy variable: } 1 \text { if the province } \\
\text { was ruled by the Habsburg dyn- } \\
\text { asty prior to unification, } 0 \\
\text { otherwise }\end{array}$ & Pécout (1999) \\
\hline
\end{tabular}


Table A1. Continued

\begin{tabular}{|c|c|c|}
\hline Variable & Construction & Main source \\
\hline Pope & $\begin{array}{l}\text { Dummy variable: } 1 \text { if the province } \\
\text { was ruled by the Pope prior to } \\
\text { unification, } 0 \text { otherwise }\end{array}$ & Pécout (1999) \\
\hline Bourbons & $\begin{array}{l}\text { Dummy variable: } 1 \text { if the province } \\
\text { was ruled by the Bourbon dynasty } \\
\text { prior to unification, } 0 \text { otherwise }\end{array}$ & Pécout (1999) \\
\hline Height & $\begin{array}{l}\text { Average height at age } 20 \text { of military } \\
\text { conscripts }\end{array}$ & A'Hearn et al. (2011) \\
\hline Population density & $\begin{array}{l}\text { Total population (in thousands) } \\
\text { living in a province (at } 1871 \\
\text { boundaries) in } 1861 \text { /provincial } \\
\text { surface in squared kilometers }\end{array}$ & $\begin{array}{l}\text { MAIC (1864), Vigo } \\
\quad(1971)\end{array}$ \\
\hline Per capita value added & $\begin{array}{l}\text { Total gross value added in agricul- } \\
\text { ture, industry, and services over } \\
\text { total population of each province } \\
\text { on the basis of census data }\end{array}$ & $\begin{array}{l}\text { Istituto Guglielmo } \\
\text { Tagliacarne (2011) }\end{array}$ \\
\hline Industrialization & $\begin{array}{l}\text { Provincial index of relative industri- } \\
\text { alization calculated on the basis of } \\
\text { census data as the share of in- } \\
\text { dustrial value added, excluding } \\
\text { construction, over the share of the } \\
\text { male population over age } 15\end{array}$ & $\begin{array}{l}\text { Ciccarelli and Fenoaltea } \\
\text { (2013) }\end{array}$ \\
\hline
\end{tabular}

to $1862-1863$. For provinces belonging to today's Veneto, data on enrollments for the first wave refer to 1856 and are from Buonazia (1870) and Vigo (1971) for primary school and Sacchi (1858) for upper primary school. For Mantua, data refer to 1851 and are from Vigo (1971) for primary school and from MAIC (1872) for upper primary school. For Rome (and Comarca), data refer to 1858 and are from Vigo (1971) for primary school and from MAIC (1872) for upper primary school.

To determine enrollment rates, we consider 6-12 (excluded) years as the relevant primary school age. In calculating lower and upper primary enrollment rates, we still employ the population 6-12 (excluded) because we have no data for the specific grade ages. Therefore, at the lower and upper level we have an unadjusted measure of enrollment (Benavot and Riddle 1988) which induces a downward bias in the measure of enrollment rates.

In some cases, gross enrollment rates are $>100 \%$, and this is due to under aged and/or overaged enrollment with respect to the school age being considered (and this is even more compelling during a period of expansion of mass education with a high incidence of late entrance). However, information on net rates (defined as the ratio between enrollments of age 6-12 years over the population of age 6-12 years) is not available. 
Family Structure and the Education Gender Gap

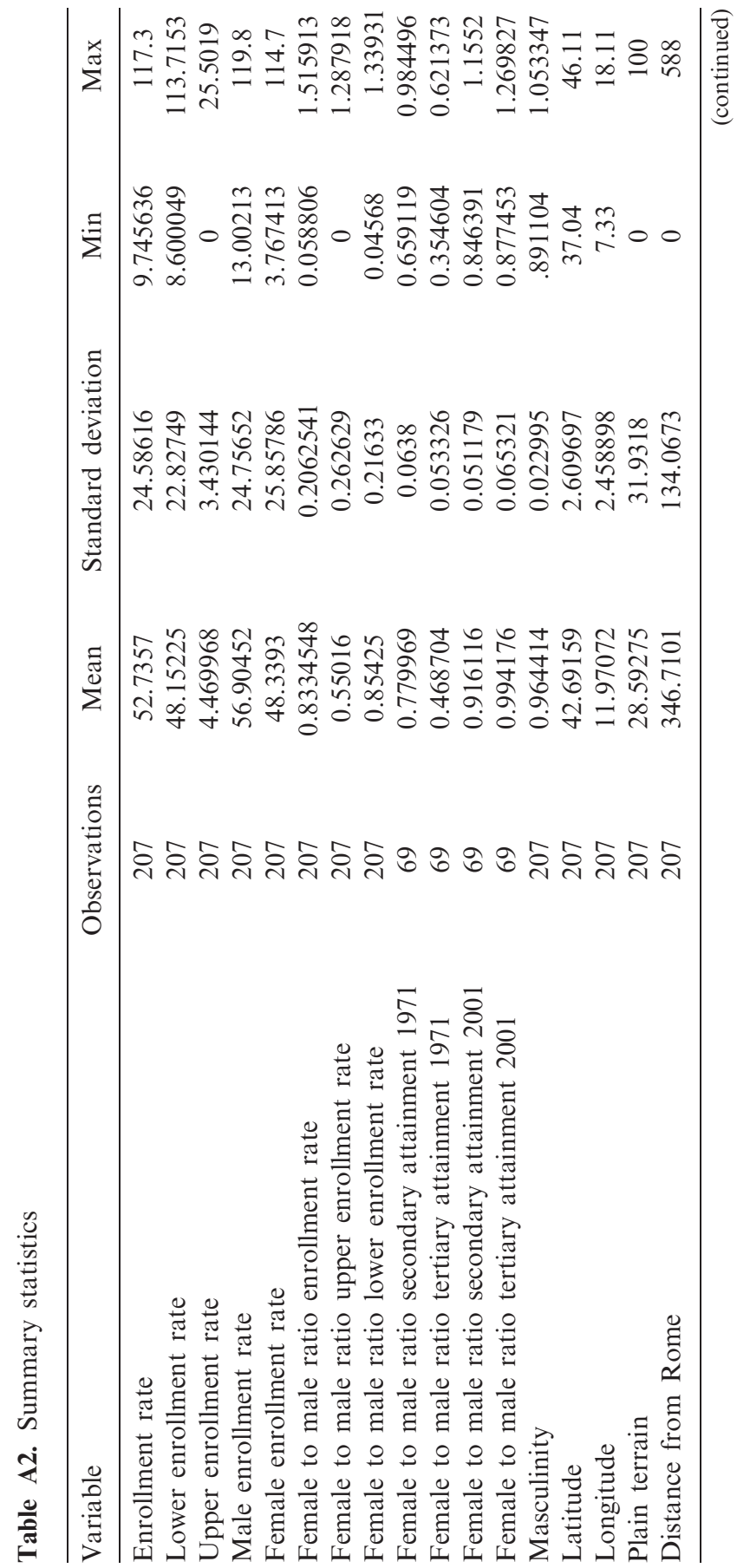


G. Bertocchi and M. Bozzano

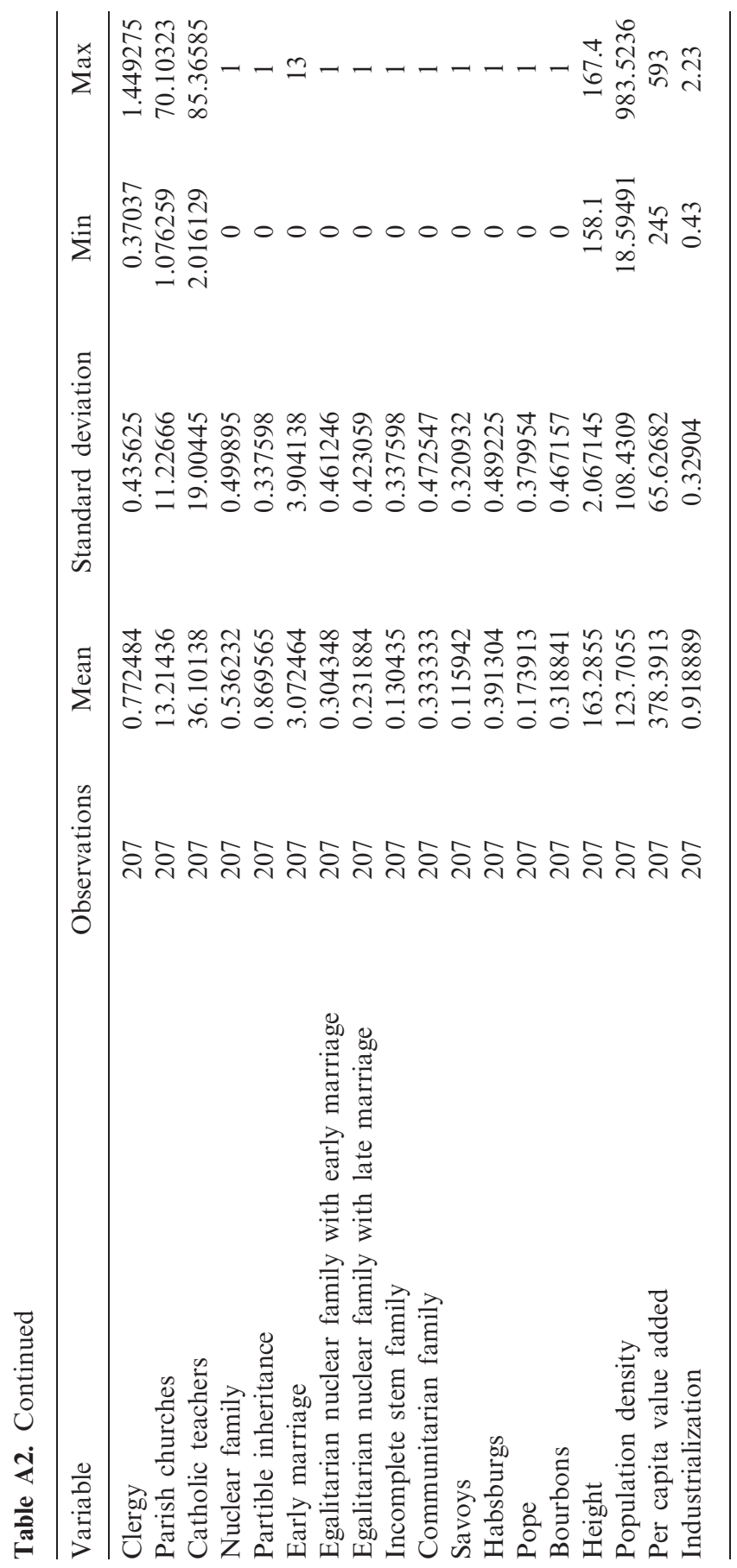


Family structure: Our first indicator is a dummy variable taking value 1 if the province was dominated by nuclear residential habits, 0 if complex ones. Our second indicator is a dummy variable taking value 1 if the province was dominated by equal partition rules of inheritance, 0 if by unequal ones. Information on both indicators is from Todd (1990). Our third indicator is the percentage of women married below the age of 15 years in 1872-1875, taken from Barbagli (1987) (the original source is DIRSTAT 1877). Finally, we adapt the classification proposed by Todd (1990) to the Italian specific regional differentiation following Hajnal (1982), Barbagli (1987), and Del Panta et al. (1996) and code provinces according to a set of four dummies, one for each family type: egalitarian nuclear with late marriage, incomplete stem, communitarian, and egalitarian nuclear family with early marriage.

Contemporaneous education data: We collect data on female and male secondary and tertiary attainment for 1971 and 2001 from national censuses (ISTAT 2009), and we obtain female-to-male ratios to be employed as our contemporaneous dependent variables. For 1971, our dependent variable is not weighted by relative population, whereas for 2001 our variables are weighted by female and male population aged 19 or more years.

Religion: We measure the influence of religion through four variables. Our first measure if the distance from Rome of the main city or town of each province in kilometers. The source is http://distanzechilometriche. net. Second, we collect information from Bianchi (1845) about the number of parish churches in each province in 1843 (the original source is Calendario Generale pei Regj Stati Sardi) and obtain their density by dividing it by the provincial surface in squared kilometers. Data on parish churches belonging to the Pope's territories are taken from Palmieri (1857) and refer to 1857. Third, we take the fraction of Catholic teachers over the total number of teachers in 1862 . The main source is MAIC (1865), and MAIC (1874) for provinces of Veneto, Mantua, and Rome. Fourth, we measure the number of clergy in 1857 (taken from Amati 1860, and Correnti 1858) per 100 individuals in the population. This fourth variable is only available at the regional, rather than provincial, level.

Political regimes: This set of binary dummy variables are intended to capture the ruling dynasties immediately prior to unification: the SavoyCarignano, who ruled in the North Western areas of Italy, that is, Piedmont, Liguria, and the island of Sardinia; the Habsburgs, who held direct control over Lombardy-Venetia, mostly in the North East, as part of the Austrian Empire, as well as indirect control over the Granduchy of Tuscany (Habsburg-Lorena) and other minor Duchies nearby (the Duchy of Modena under Este of Austria, the Duchy of Parma and Piacenza, and the Duchy of Massa Carrara under Habsburg-Lorena); the Pope, reigning 
over Rome and the Center South; and the Bourbons, in charge of the South and the Duchy of Lucca. Even though the latter falls under the Habsburgs in 1847, we consider it as dominated by the Bourbons throughout the 1816-1861 period. Information is from Pécout (1999).

Height: Data about wealth of ancient Italian provinces are not available. For this reason, we employ height as a proxy for wealth. In the economic history literature, it is common to make use of anthropometric measures because they provide important indirect information on changes in the well-being of the population. Data on height refer to the mean height of military conscripts aged 20 years at the provincial level and are taken from A'Hearn et al. (2011). For an exhaustive presentation of the use of this kind of anthropometric data as a plausible proxy for well-being and living standards, see A'Hearn et al. (2011, ch. 2). For a discussion about the methodological approach employed to estimate average height, see A'Hearn et al. (2009).

Population density: We collect data about the total population living in each province in 1861 from the census (MAIC 1864) and, for provinces belonging to Veneto, Mantua, and Rome, from Vigo (1971). We divide it by total surface of the province in squared kilometers.

Per capita value added: Data on per capita value added at the provincial level are taken from the estimates of the Istituto Guglielmo Tagliacarne (2011) which has calculated total gross value added in agriculture, industry, and services over total population of each province on the basis of census data. For a detailed explanation of the employed methodology for these estimates, see Istituto Guglielmo Tagliacarne (2011). Data for the first wave for the provinces belonging to today Veneto, Mantua, and Rome refer to year 1871 .

Industrialization: Data on industrialization at the provincial level are taken from Ciccarelli and Fenoaltea (2013, Table 2). The variable is a provincial index of relative industrialization calculated on the basis of census data as the share of industrial value added, excluding construction, over the share of the male population over age 15 years. Ciccarelli and Fenoaltea (2013) explain that using this age/sex group provides the best proxy of local GDP because adult males represented the most mobile and flexible segment of the labor force and also because male labor force participation rates are uniformly high and not clouded, as female rates are, by varying local conventions. Data for the first wave refer to 1871 . 